\title{
FEMININE AND RELIGIOUS LEADERSHIP. A LONG TERM COMPANY MODEL
}

\section{LIDERAZGO FEMENINO Y RELIGIOSO. UN MODELO DE EMPRESA A LARGO PLAZO}

\author{
MARIA VICTORIA SANAGUSTÍN-FONS \\ Universidad de Zaragoza \\ JULIANNA PAOLA RAMÍREZ-LOZANO \\ CENTRUM-Pontificia Universidad Católica del Perú \\ RENATO PEÑAFLOR-GUERRA \\ Universidad Peruana de Ciencias Aplicadas (UPC)
}

Recibido: 03/04/2019 Aceptado: 19/06/2019

\section{ABSTRACT}

We analyse a case of successful family business with an ethical and religious management and orientation. Both the founder and her successor are women, so the model of entrepreneurship is very unique, also because the organization is in an emergent economy.

Through the Case Study using documentary analysis and quantitative methodology, we have reached empirical keys to understand how a small Peruvian Company can survive over 70 years as leader in a specific market. All this is based on the feminine leadership and the construction of a solid culture created by its founder.

We found that it is a company whose growth and sustainability over time is due to the close presence of its founder. A specific leadership followed by her successor who has strong religious values and is managing to add creativity and innovation. The 
founder has been a leader close to her workers, who has been able to lead by example, always with humility, austerity and showing concern for her collaborators. "Ora et labora" is the motto of the company and highlight its main goals as quality, service and high commitment with the society in which is embedded.

Keywords: organizational culture and religiosity, business ethics, leadership, feminine family business.

\section{RESUMEN}

Analizamos un caso de empresa familiar de éxito con una gestión y orientación ética y religiosa. Tanto la fundadora como su sucesora son mujeres, por lo que el modelo de empresa es muy singular, también porque la organización se encuentra en una economía emergente.

A través del Estudio de Caso utilizando análisis documental y metodología cuantitativa, hemos llegado a claves empíricas para entender cómo una pequeña empresa peruana puede sobrevivir más de 70 años como líder en un mercado específico. Todo esto se basa en el liderazgo femenino y en la construcción de una sólida cultura creada por su fundador.

Encontramos que es una empresa cuyo crecimiento y sostenibilidad en el tiempo se debe a la estrecha presencia de su fundador. Un liderazgo específico seguido por su sucesora que tiene fuertes valores religiosos y que consigue añadir creatividad e innovación. La fundadora ha sido una líder cercana a sus trabajadores, que ha sabido dar ejemplo, siempre con humildad, austeridad y preocupación por sus colaboradores. "Ora et labora" es el lema de la empresa y destaca sus principales objetivos como la calidad, el servicio y el alto compromiso con la sociedad en la que está inserta.

Palabras clave: cultura organizacional y religiosidad, ética de negocios, liderazgo, negocios familiares femeninos.

\section{INTRODUCTION}

Ethical management and a unique powerful leadership (Meens \& Molinaro, 2016) oriented to a certain organizational culture has two main important variables that guarantee the successful organization of a family business. Even more, if the leader of the Company is an immigrant German woman (Faraudello \& Songini, 2018) with strong religious beliefs and work values, inside a 
developing country as Peru, founding the company at the end of 40's decade of past century, the consequence is a firm with strong familiness (work and workers oriented culture) and high commitment with the Peruvian social accepted values (Cortina, 1994); with a high social and economic recognition inside the society in which this company is embedded.

The transversal gender variable in this case study is presented both from up to bottom and vice versa. Research suggests that women tend to adopt leadership styles that are particularly well suited for the complexity of contemporary organizations and can translate into enhanced institutional effectiveness (Eagly and Carli, 2003, Eagly et al., 2014 in Hoyt \& Murphy, 2015). Furthermore, women can bring unique and important perspectives and priorities that serve to promote positive social outcomes and greater ethical accountability (Eagly et al., 2014 in Hoyt \& Murphy, 2015). However, the realization of these potential advantages can be hampered by the disadvantage female leaders experience as the target of negative stereotype-based expectations (Hoyt \& Murphy, 2015). Our main hypothesis is that this kind of business project has to lead with a complex society which has, sometimes, opposite cultural values such as certain level of machismo, and the idea that the leader must be a man with high authoritarian style. So, the research questions are: What is the impact achieved by an ethical leadership and culture in the business sustainability of family businesses? Which are the values of the company? Are all these in relation to socio-emotional objectives, stewardship and familiness? How do religious or spiritual beliefs affect the morale of the family members, family ethics and governance?

\section{THEORETICAL FRAMEWORK}

The conceptual axes can be described through four main different organizational culture dimensions, which are divided into a) intra-organizational family relationships and familiness into business culture, b) company's feminine business ethics based on the founder's religiosity \& stewardship.

A) INTRA-ORGANIZATIONAL FAMILY RELATIONSHIPS AND FAMILINESS INTO BUSINESS CULTURE

In family companies, the family relationship inside the organization is always present (Gómez Mejía et al 2014; Astrachan et al., 2018). So, familiness is a real feature of these kind of companies (Cruz et al., 2014; Frank et al., 2016). 
Also, family firms - because of their concern with SEW (socioemotional wealth) - may be more likely to adopt the instrumental and selective rather than strategic (holistic) and normative approach to CSR (Corporate Social Responsibility) (Zientara, 2015) and even to BE (Business Ethics) due to the existence of implicit codes of conduct with deep values inside (Sanagustín-Fons, 2011) and this gives a long term success to these businesses (Kenyon-Rouvinez, 2017). Specially those companies where the leader is a woman; in a metaanalysis Hobbler et al. (2016) shown that women's leadership - overall and, specifically, the presence of a female CEO - is more likely to positively related to firms' financial performance in more gender egalitarian cultures (Hoobler et al., 2018).

The competitiveness of family firms is connected to some research results which suggest that family business employment is positively associated with employees' innovative work involvement, and that part of this relationship can be attributed to their heightened perceptions of organizational support and work motivation (Bammens et al, 2014). Also, family firms will be less vulnerable due to greater risk aversion and the propensity to develop strong long-term relationships that promote stability even in the face of crisis (Maloni et al., 2017). Family businesses represent the majority of companies and are an important source for the generation of jobs in most countries. Longevity is very important for the family businesses and for economies as a whole (Ramadani \& Hoy, 2015).

Consequently, organizational culture is a unique one in this kind of companies (Ramadani \& Hoy, 2015). The permanence of culture over time allows people to learn, adapt and even change their behaviour, values, beliefs, traditions, attitudes and habits (Hamilton et al., 2017). Neubauer and Lank (2016) states that culture is like the configuration of a learned behaviour, whose elements are shared and transmitted by the members of a community. It is interesting to understand, and above all, to pay attention to how these members that can change behaviours in the rest of the business community. Nowadays, it is no longer a secret that the heads of the working groups, managers, directors and founders, who have the opportunity to lead their colleagues cannot do it without attitudes and leadership skills allowing people to a psychological engagement (Ramos et al., 2014); considering that the individual-level behaviours and firm-level governance mechanisms that predict organizational outcomes are present in family businesses (Madison et al., 2015)

It is important that the entire company takes care of the leadership, because leaders are a fundamental piece in the organizational culture. The honourable 
and complicated mission of taking care of the elements of this, defining the direction of the organization carried out by motivated or demotivated collaborators towards success or failure. Regarding the Theory of Organizations, Costa (2012, p. 135) understands that "it can be considered that the culture allows (large) companies to work, since it is predictable -by the internalization of values and norms- the behaviour of diverse individuals who have integrated the culture". Anzola (2003), recalls that Hofstede (2011) emphasize the main characteristics of culture. Among which we can give priority to the identity of the members, the approach towards people, control, criteria to reward, tolerance to conflict, the approach towards an open system. So, family companies have a deep and strong organizational culture.

\section{B) COMPANY'S FEMININE LEADERSHIP BASED ON THE FOUNDER'S RELIGIOSITY \& STEWARDSHIP}

Lussier and Achua (2016, p. 5), say that "there is no universal definition of leadership due to its complexity as it studies in different ways that require different definitions". However, it's important to say that it basically deals with the ability of an individual to influence others. This is oriented towards the tasks and objectives of a team, not only personal. Different researchers agree that leadership in a person is something natural and learned or developed (Northouse, 2018). The importance is exercising an ethical leadership, as Lussier and Achua (2016) refer, in the first place it is the right thing; and second, the right behaviour because unethical actions bring serious financial and image consequences to the company. The authenticity of the leader is gestated in its values, emotions and beliefs. In addition, Lussier and Achua (2016) indicates that this also requires courage and character, mainly to face difficult moments and make decisions that may not even be popular in the environment. Also, strategic thinking and flexibility are key to work with others and follow the same line with respect without fear. Different authors agree in relation to the effectiveness of this kind of leadership (Copeland, 2016); in a research about family business, Mussolino and Calabrò (2014) show how predecessor's different paternalistic leadership styles influence family successor's beliefs in family firms and how benevolent and moral paternalistic leadership style of the predecessor have a positive effect on successor's behaviour.

The socio-emotional objectives in the Company run together the stewardship theory that explain the management orientation of the Company, different studies shown, that the comparison between females and males applying Servant Leadership Questionnaire across K-12, females were 
significantly higher than males on emotional healing, wisdom, persuasive mapping and organisational stewardship (Xu et al, 2015), in general female leaders display more servant leadership characteristics, regardless of whether they exhibit them or not (Politis \& Politis, 2018).

So, small businesses with a feminine leadership based on strong religious and stewardship values represent a model of successful and ethical companies with resilience, permanence and market stability, even more, the company looks like an extension of the Founder's aim, goals and spirituality representing a social fabric in permanent reconstruction. In this research we are going to show that through a Case Study in the Peruvian market. After this, we propose a theoretical reflection on a kind of specific organizations: feminine, family, small, ethical and religious ones.

\section{METHOD}

A Case Study research has been developed following two methodological steps and phases using Cummings and Worley (2014) strategy to research organizations development and culture (see Table 1). First of all, documentary analysis has had a double orientation, the theoretical framework of the research and a description of the Company Arti S.A., a traditional family Peruvian SMEs with a German immigrant woman as its founder, and its current economic statement; it is also described a brief history of this Company which is in the Peruvian market after 70 years. Secondly, a survey focused on the workers'/ collaborators' perception of the company and their work satisfaction, based on Hofstede's organizational culture model was hold during summer time of 2018 (Annex I). 
Table 1: Case Study Research Strategy

\begin{tabular}{|c|c|c|c|c|c|}
\hline & $\begin{array}{l}\text { Social } \\
\text { Research } \\
\text { Techniques }\end{array}$ & Data Base & Study goal & $\begin{array}{l}\text { Empirical } \\
\text { Perspective }\end{array}$ & Temporary \\
\hline $\begin{array}{l}\text { Method } \\
\text { Approach. } \\
\text { Phase I }\end{array}$ & $\begin{array}{l}\text { Documentary } \\
\text { Analysis }\end{array}$ & $\begin{array}{l}\text { - } \\
\text { Bibliographic } \\
\text { Data } \\
\text {-Economic } \\
\text { Reports } \\
\text {-Company's } \\
\text { Data Base } \\
\end{array}$ & $\begin{array}{l}\text {-General } \\
\text { Theoretical } \\
\text { Framework } \\
\text { Perspective } \\
\text {-Company \& } \\
\text { Economic } \\
\text { Statement }\end{array}$ & Descriptive & $\begin{array}{ll}\begin{array}{l}\text { Five last } \\
\text { years }\end{array} & \end{array}$ \\
\hline $\begin{array}{l}\text { Method } \\
\text { Approach. } \\
\text { Phase II. }\end{array}$ & Surveys & Own & $\begin{array}{l}\text { Sample of } \\
\text { Peruvian }\end{array}$ & Quantitative & $\begin{array}{l}\text { July, August } \\
\& \\
\text { September, } \\
2018\end{array}$ \\
\hline
\end{tabular}

Source: own elaboration

\section{RESULTS ANALYSIS}

\section{A BRIEF HISTORY OF ARTI S.A.}

The company Arti S.A. was founded on March 27, 1948, as result of the initiative and entrepreneurship of the Schreier Reck family, German immigrants and in particular Mrs. Eva Reck who was in charge of the leadership of the company. The company in its beginnings was dedicated to the production of dyes and anilines for textile dyeing.

In 1952, the Schreier Reck family achieved the exclusive representation, for production and distribution, of cosmetics (Badedas bath gel, among others) and UHU glues, at that time both brands belonged to the same company, UHU Werk H.u.M. Fisher - Bühl, both brands of German origin. In its first decades, Arti S.A. strengthens its position achieving to become a leader in those products. During the 60s and 80s the company faced difficult times conditioned by the situation of the country, such as the time of the military government, times of high inflation and difficult to obtain foreign currency. However, the company had to organize the production and sales with little staff.

Mrs. Eva Reck, founder and leader, managed to start the machinery for production, counting on the professional support of her husband Gerhard Schreier Mock, who provided technical service for many years. It was also very 
important the support she had in her staff - some of whom, still work at Arti S.A., and have more than 40 years of service to the company. In the $90 \mathrm{~s}$, the company decided to strengthen the product portfolio and obtained the representation of Stabilo, the leading German brand of writing tools. " $\mathrm{A} \mathrm{few}$ years later we obtained the representation of Linex (Danish precision items) and Bantex (archival and office utilitarian material) and Kum (German high quality workers)". Arti S.A. at the end of the 90s also ventures into that time in the distribution of world-renowned brands such as Paper Mate, 3M, Kodak, Imation, Epson, Lexmark, HP, Duracell.

In 2003, the company developed its own creative Arti S.A. brand, innovating and occupying a niche in the market with the production of tempera and finger paint. Today the line has more than 500 items from the ludicpedagogical line, which evokes creativity and free expression through colour. In 2006, BIC entrusts Arti S.A. with the distribution of its products in writing lines, shaving and lighters. In the following years, brands such as Sadipal and Fabriano, global leaders in fine stationery, are added to the representation portfolio; and other important brands.

Since 2010, the company has placed special emphasis on the professionalization of the management team and set up an executive committee made up of independent professionals to support the company management. Currently, Arti S.A. reports an annual turnover that places it among the main contributors of the sector, thanks to its sales team, promoters and merchants, who attend the traditional channel at the national level (bookstores, bazaars, trimmings, pharmacies, hardware stores), as well as as to the modern channel (self-service, department stores). In the period from 2007 to 2016 a CAGR (Compound Annual Growth Rate) was obtained in sales of $7.4 \%$ with EBITDA (Earnings Before Interest, Taxes, Depreciation, and Amortization) of around $6 \%$ of sales. In relation to the financial strategy, the strategic actions are grouped into 3 main topics which are: 1) Operational Efficiency; 2) Brand positioning - Arti S.A. Creativo and 3) Commercial Effectiveness - Best trained sellers. Arti S.A. has a good financial statement: the gross operating margin stands at $37 \%$; and the level of sales runs over the Peruvian economy development (Arti S.A., 2018).

In the future, the company is focused on developing greater synergies with local and foreign suppliers, continuing with the modernization of the organizational structure and internal processes with the support of information technologies. 


\section{QUANTITATIVE ANALYSIS DATA}

The profile of the 77 Arti S.A. employees is: $24.7 \%$ male and $75.3 \%$ female. It is also mostly experienced workers in adulthood, since $75.3 \%$ of them are over 35 years of age, while $24.7 \%$ are between 26 and 35 years old, and only $9.1 \%$ have less than 26 years of age. So, the profile is an adult woman working in the company between 6 and 15 years (see Table 2).

Table 2. Time spent working in the Arti S.A. company according to sex of the correspondent $\%$ due to respondent's sex

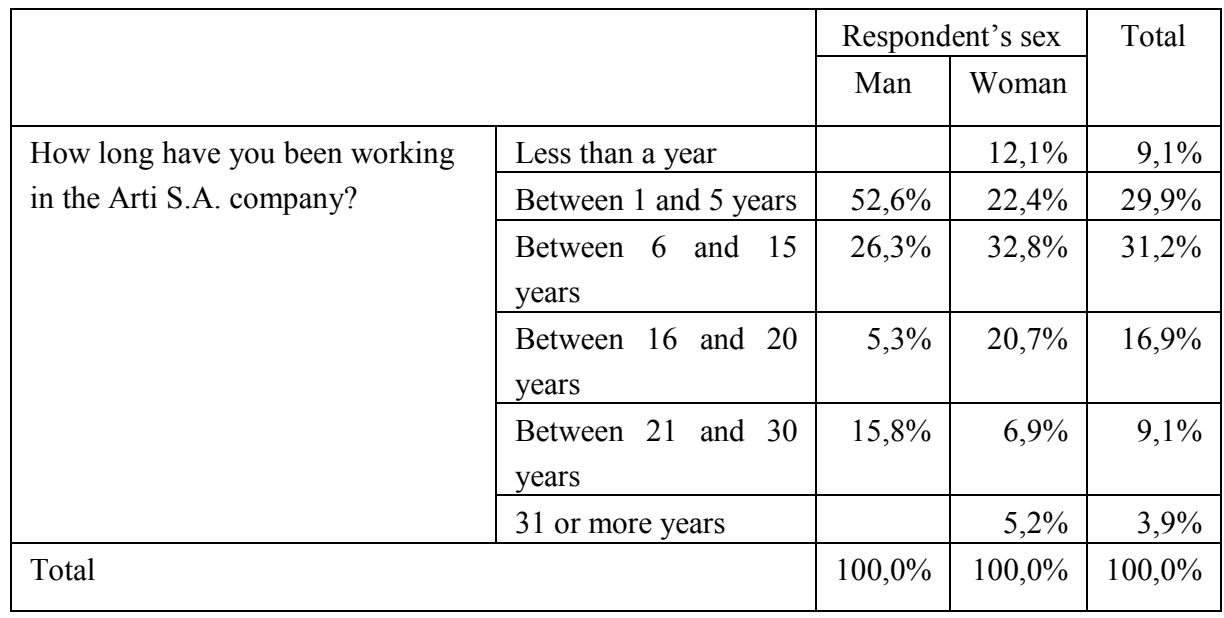

Source: Own elaboration

The time spent in the company, about $61 \%$ of respondents indicate that they have been working for more than 5 years. It is among the women that the greatest differences in both ends of the time of permanence are observed. While $32.8 \%$ have been working for Arti S.A. for more than 15 years (compared to $21.1 \%$ of men in the same condition), it should also be noted that they are basically the ones that become the generational replacement $(12.1 \%$ are less than 1 -year-old in Arti S.A.), as shown in Fig. 1. 
Fig. 1: Years worked in the company and sex of the workers (\% by sex of respondents)

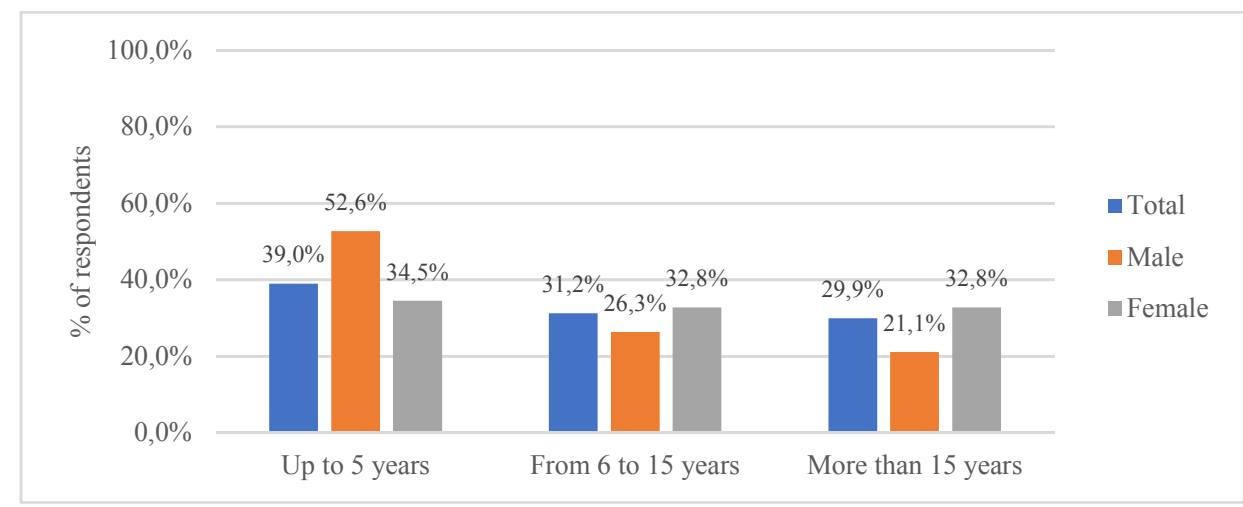

Source: Own elaboration

A positive situation is found in the personal relationship of the employee with the different areas of the company (Question 7) (see Fig. 2); taking into account that the scale was done under a five points of choice, being 1: strongly agree and 5: strongly disagree. The attribute of "I feel that the company pays me fairly and proportionally to my work" is the best qualified, with a mean of 2.742, statistically different from the other attributes, except for the average rating of the attribute "Ifeel I can recommend a friend or relative to the Arti S.A. company to work" $^{\prime \prime}(2,623)$, whose means are not statistically different $(\mathrm{t}=0.795$ and Prob $=0.999)$.

The attribute "I feel I can recommend a friend or relative to the Arti S.A. company to work" with mean 2.623 is only not statistically different from the means of the attributes "I feel that the company pays me fairly and proportionally to my work" (means $=2.742, \mathrm{t}=0.795, \operatorname{Pr}=0.999)$, to "I feel that the company cares about me and my family" (means=2.192, $\mathrm{t}=2.877, \operatorname{Pr}=0.122$ ) nor to "I feel that the company worries about communicating what happens in the company" (means=2.196, $\mathrm{t}=3.156, \mathrm{Pr}=0.059$ ). However, the probability of the last attribute is not that high, which shows that it is close to providing evidence of significant means differences. So, it could be indicated now that these two attributes ("I feel that the company pays me fairly and proportionally to my work" and "I feel I can recommend a friend or relative to the Arti S.A. company to work") tend to be the most criticized by the respondents. There are no statistically different means by sex, which indicates that it cannot be said that the attributes would be valued differently between men and women. And in relation the age, only the means of the attribute of "Ifeel that the founder is close 
to me and the needs of the company" (2.315 between employees from 18 to 35 years and 1.862 from 36 years old and over) are statistically different $(\mathrm{t}=2.042$, Prob $=0.045$ ). This implies that younger people feel more distant from the figure of the founder.

Results indicate that the most recent employees tend to be more critical of the company's concern for them compared to older employees, as shown, in the attribute "I feel that the company cares about me and my family", the means of 2.567 among employees with permanence up to 5 years is statistically higher than the 1.740 found among employees with more than 15 years $(t=3.234$, Prob=0.005). In the attribute of "I feel that the founder is close to me and the needs of the company", the employees with the shortest time of permanence are the most critical, the means of 3.499 among employees with permanence up to 5 years is statistically higher that the 2,791 found among employees between 6 to 15 years $(t=3.465$, Prob $=0.003)$ and 2.478 among employees of 16 to more years of permanence $(\mathrm{t}=4.942$, Prob $=0.000)$. This indicates that the youngest feel more distant with the founder, as well as that people of 6 to 15 years of permanence and those of 16 and over think similarly. Finally, in the attribute " $I$ feel that the CEO is close to me and the needs of the company", the means of 3.334 among employees with permanence up to 5 years is statistically higher than the 2.608 found among employees with more than 15 years $(t=3.158$, Prob $=0.006$ ). This indicates that the most recent employees tend to be more critical with the closeness of the CEO to the employees compared to the ones with the highest trajectory in the company. 
Fig. 2: Relationship of the employee with the different areas of the organization ( $\%$ of the total number of respondents)

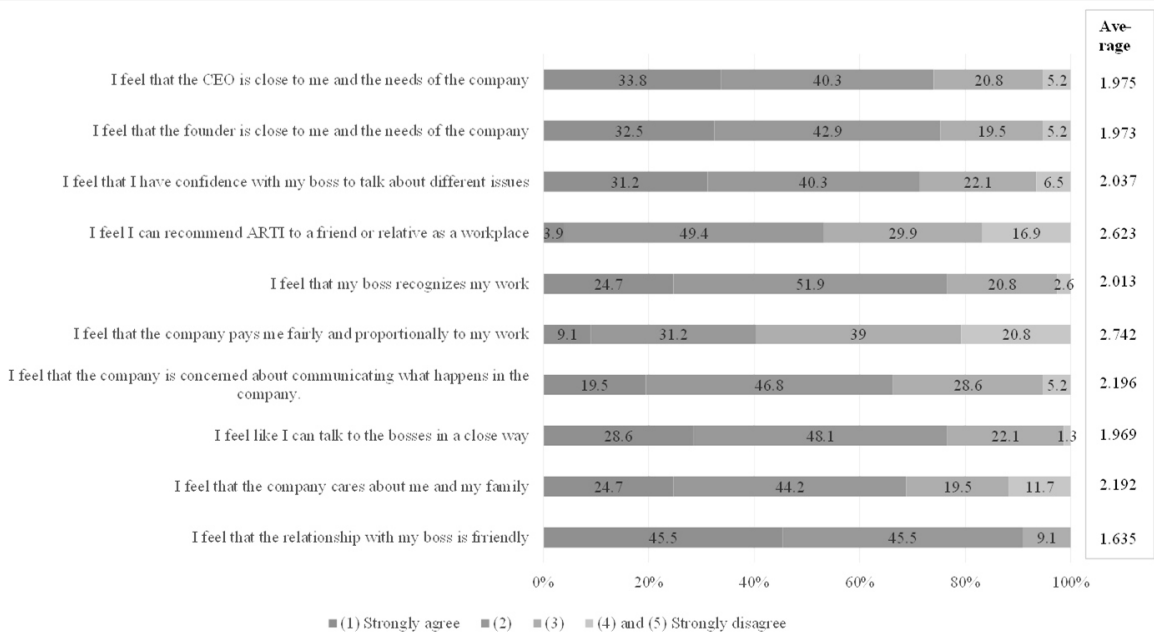

Source: own elaboration

The relationship with the direct manager (1,635 means rating, with $45.5 \%$ of respondents who assigned the value of 1 to the attribute, the best possible rating) and the perceived closeness with the founder of the organization $(1,973$ means and 32.5\% qualification 1) and with the Executive Director (1,975 means and $33.8 \%$ qualification 1) are the best qualified elements in the relationship with the company. On the contrary, the aspects less valued by the staff revolve around the perception of the remunerative level in relation to the effort they dedicate to the company (2,742 on means and $20.8 \%$ of negative ratings 4 and 5 ) and the possibility of recommending Arti S.A as a place of work for a close person $(2,623$ means and $16.9 \%$ negative ratings $)$.

In Fig. 3 is shown the level of employee satisfaction with their position in the Company, second thematic axis of the instrument, the evaluation focused on employee satisfaction with the different characteristics of the organization and its labour supply. Here, at a general level, a favourable scenario could be found again, since all the evaluated elements are in the area of positive values of the scale applied ( 2 or less). However, there are elements of satisfaction that should be highlighted, such as the treatment between co-workers (1,909 of means rating with $29.9 \%$ of mentions that assigned the rating of 1) and the rules and regulations that have been applied in the company. $(1,974)$, to which the 
working hours $(2,037)$ and the relationship with the superiors $(2,039)$ can be combined. Meanwhile, on the other hand, it is clear that the aspects that can be improved in the case of Arti S.A are the work uniform that is used on a daily basis $(2,647)$ and the remuneration received $(2,858)$, providing new evidence on the unfavourable position of the workers toward a sense of equity between the effort made and the monetary recognition that the organization provides.

Fig. 3: Level of employee satisfaction with their position in the organization ( $\%$ of the total number of respondents)

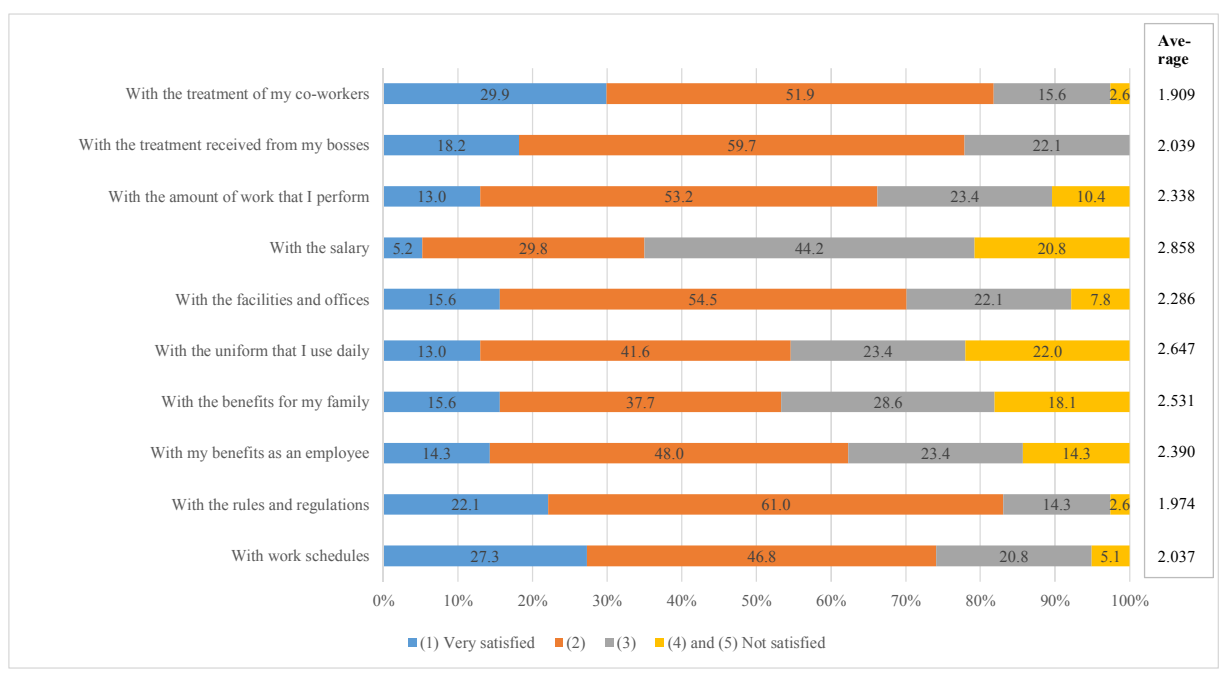

Source: own elaboration

At a general level data gives us, in relation to satisfaction (Question 8) first "with the salary" shows an average (2.858) statistically higher than most attributes evaluated, except for satisfaction "with the benefits for me as an employee" with an average of $2.390(\mathrm{t}=3.119$, Prob=0.065), "with the benefits for my family" with an average of $2.531(\mathrm{t}=2.040$, Prob=0.574), and "with the uniform that I use daily" with an average of $2.647(\mathrm{t}=1.224$, Prob=0.968). This establishes that, at a general level, these are the least satisfactory elements among the surveyed employees.

According to the results of the tests of differences of means, it can also be observed that the average of 1.909 of the level of satisfaction "with the treatment of my co-workers" is statistically different from the four attributes mentioned 
above, being between the most valued satisfaction elements. However, this attribute does not significantly differentiate from the average of 2.037 "with working hours" ( $\mathrm{t}=-1.019$, Prob=0.991), mean of 1.974 by "with the rules and regulations" ( $\mathrm{t}=-0.562$, Prob=1.000), the average of 2.286 "with the facilities and offices" ( $\mathrm{t}=-2.700$, Prob=0.185) and 2.039 by the attribute "with the treatment of my bosses" ( $\mathrm{t}=-1.162$, Prob=0.977). From this, can be considered that the level of satisfaction with the treatment of co-workers it is not the most valued but it is among the best qualified.

The level of the employee satisfaction of the respondents shows no significant mean differences neither by age (Table 3 ) or by sex 5 . But in relation to the employee's time of permanence in the company, people with the longest permanence are clearly more satisfied with the following aspects than those who have 5 or less years in the organization: a) satisfaction "with the benefits for me as an employee", with averages of 1.826 and 2.833 respectively $(\mathrm{t}=3.006$, Prob=0.010); b) satisfaction "with the benefits for my family", with averages of 1.870 and 3.034 respectively $(\mathrm{t}=3.184$, Prob $=0.007)$ and, c) satisfaction "with the uniform that I use daily", with averages of 2.041 and 2.934 respectively $(\mathrm{t}=4.289$, Prob $=0.000)$. On the other hand, it is demonstrated that the most experienced employees (with more than 15 years of experience in the company) are clearly more satisfied than those who are up to 5 years old and also those from 6 to 15 years of permanence:a) satisfaction with facilities, where the segment with the longest stay shows an average of 2.086, compared to 2.300 $(\mathrm{t}=-04.280$, Prob=0.000) and 2.458 $(\mathrm{t}=-2.764, \mathrm{Prob}=0.022)$ of the other two; $\mathrm{b})$ satisfaction with the salary, where the segment with the longest stay shows an average of 2.566, compared to $3.000(\mathrm{t}=-4.463$, Prob=0.000) and $2.958(\mathrm{t}=-$ 2.447 , Prob $=0.044$ ) of the other two and c) satisfaction with the amount of work performed, where the segment with the longest stay shows an average of 1.955, compared to $2.400(\mathrm{t}=-4.798$, Prob=0.000) and $2.625(\mathrm{t}=-2727$, Prob $=0.025)$ of the two others. 
Table 3. Level of employee satisfaction with their position in the organization (in \% per age of the respondents)

\begin{tabular}{|c|c|c|c|c|c|c|c|c|}
\hline \multirow[b]{3}{*}{ Attribute } & \multicolumn{8}{|c|}{$\begin{array}{c}\text { Rating scale } \\
\text { (in \% of respondents) }\end{array}$} \\
\hline & \multirow{2}{*}{\multicolumn{2}{|c|}{ Age }} & \multicolumn{3}{|c|}{$\begin{array}{l}\text { Very } \\
\text { satisfied }\end{array}$} & \multicolumn{2}{|c|}{$\begin{array}{c}\text { Not } \\
\text { satisfied }\end{array}$} & \multirow{2}{*}{$\begin{array}{l}\text { Scale } \\
\text { Means }\end{array}$} \\
\hline & & & 1 & 2 & 3 & 4 & 5 & \\
\hline \multirow[t]{2}{*}{ With work schedules } & $\begin{array}{l}\text { Between } \\
\text { and } 35\end{array}$ & 18 & 21.1 & 52.5 & 21.1 & 5.3 & & 2.106 \\
\hline & 36 and over & & 29.3 & 44.8 & 20.7 & 5.2 & & 2.018 \\
\hline \multirow[t]{2}{*}{ With the rules and regulations } & $\begin{array}{l}\text { Between } \\
\text { and } 35\end{array}$ & 18 & 15.8 & 57.8 & 21.1 & 5.3 & & 2.159 \\
\hline & 36 and over & & 24.1 & 62.1 & 12.1 & 1.7 & & 1.914 \\
\hline \multirow[t]{2}{*}{ With my benefits as an employee } & $\begin{array}{l}\text { Between } \\
\text { and } 35\end{array}$ & 18 & 10.6 & 57.8 & 15.8 & 15.8 & & 2.368 \\
\hline & 36 and over & & 15.5 & 44.8 & 25.9 & 12.1 & 1.7 & 2.397 \\
\hline \multirow[t]{2}{*}{ With the benefits for my family } & $\begin{array}{l}\text { Between } \\
\text { and } 35\end{array}$ & 18 & 15.8 & 36.8 & 26.3 & 15.8 & 5.3 & 2.580 \\
\hline & 36 and over & & 15.5 & 37.9 & 29.3 & 13.8 & 3.5 & 2.519 \\
\hline \multirow[t]{2}{*}{ With the uniform that I use daily } & $\begin{array}{l}\text { Between } \\
\text { and } 35\end{array}$ & 18 & 5.3 & 52.5 & 26.3 & 10.6 & 5.3 & 2.581 \\
\hline & 36 and over & & 15.5 & 37.9 & 22.4 & 12.1 & 12.1 & 2.674 \\
\hline \multirow[t]{2}{*}{ With the facilities and offices } & $\begin{array}{l}\text { Between } \\
\text { and } 35\end{array}$ & 18 & & 78.9 & 21.1 & & & 2.211 \\
\hline & 36 and over & & 20.7 & 46.6 & 22.4 & 1.7 & 8.6 & 2.309 \\
\hline \multirow[t]{2}{*}{ With the salary } & $\begin{array}{l}\text { Between } \\
\text { and } 35\end{array}$ & 18 & 5.3 & 36.8 & 36.8 & 21.1 & & 2.737 \\
\hline & 36 and over & & 5.2 & 27.5 & 46.6 & 13.8 & 6.9 & 2.897 \\
\hline \multirow[t]{2}{*}{$\begin{array}{l}\text { With the amount of work that I } \\
\text { perform }\end{array}$} & $\begin{array}{l}\text { Between } \\
\text { and } 35\end{array}$ & 18 & 10.6 & 52.5 & 26.3 & 10.6 & & 2.369 \\
\hline & 36 and over & & 13.8 & 53.4 & 22.4 & 6.9 & 3.5 & 2.329 \\
\hline \multirow[t]{2}{*}{$\begin{array}{l}\text { With the treatment received from } \\
\text { my bosses }\end{array}$} & $\begin{array}{l}\text { Between } \\
\text { and } 35\end{array}$ & 18 & 10.6 & 68.3 & 21.1 & & & 2.105 \\
\hline & 36 and over & & 20.7 & 56.9 & 22.4 & & & 2.017 \\
\hline \multirow[t]{2}{*}{$\begin{array}{l}\text { With the treatment of my co- } \\
\text { workers }\end{array}$} & $\begin{array}{l}\text { Between } \\
\text { and } 35\end{array}$ & 18 & 26.3 & 68.4 & 5.3 & & & 1.790 \\
\hline & 36 and over & & 31.0 & 46.6 & 19.0 & 3.4 & & 1.948 \\
\hline
\end{tabular}

Total: $100 \%$ horizontal

Source: Own elaboration 
The last group of attributes evaluated is related to employees' perception of Arti S.A. strategies that would have allowed the company to reach their current situation. In this regard, all strategic elements receive a favourable rating, demonstrating that from the point of view of employees the company has not based its performance only on attributes related to the product, financial management, processes or service, but also aspects related to the culture and leadership of the main actors of the organization. It is interesting to see in Fig. 4 the way in which the leadership of the founder stands out over the other strategic elements (means score of 1,468), which is something that the companies include to differentiate themselves from the competitors.

Regarding culture, this is an aspect whose mean (1.922) does not distance itself statistically from the others, except for the perception of the founder's leadership (1.468) where it receives a clearly lower means $(t=5.327$, Prob $=0.000$ ), so, the level of perception is hgher. Only in the strategic attribute of "good administrative and management processes" there are significant differences between men and women $(\mathrm{t}=2.187$, Prob=0.032), where men show a mean of 2.526 and women of 2.102. Women are the ones who most agree with the fact that administrative and management processes are one of the main columns in the fact that Arti S.A. remains in the market.

There are statistically significant differences in the perception of the founder's leadership as a strategic element according to the employee's age $(t=3.089$, Prob $=0.003)$. This implies that employees 18 to 35 years of age consider it to be a less relevant element (average of 1.789) than those surveyed from 36 years and over (average of 1.362). There are no significant differences in the means of perception of the different strategic elements evaluated according to the time the respondent has been working in the organization (see Table 4). 
Fig. 4: Perception of the strategies implemented that would have allowed Arti S.A. to operate 70 years in the market (in $\%$ of the total number of respondents)

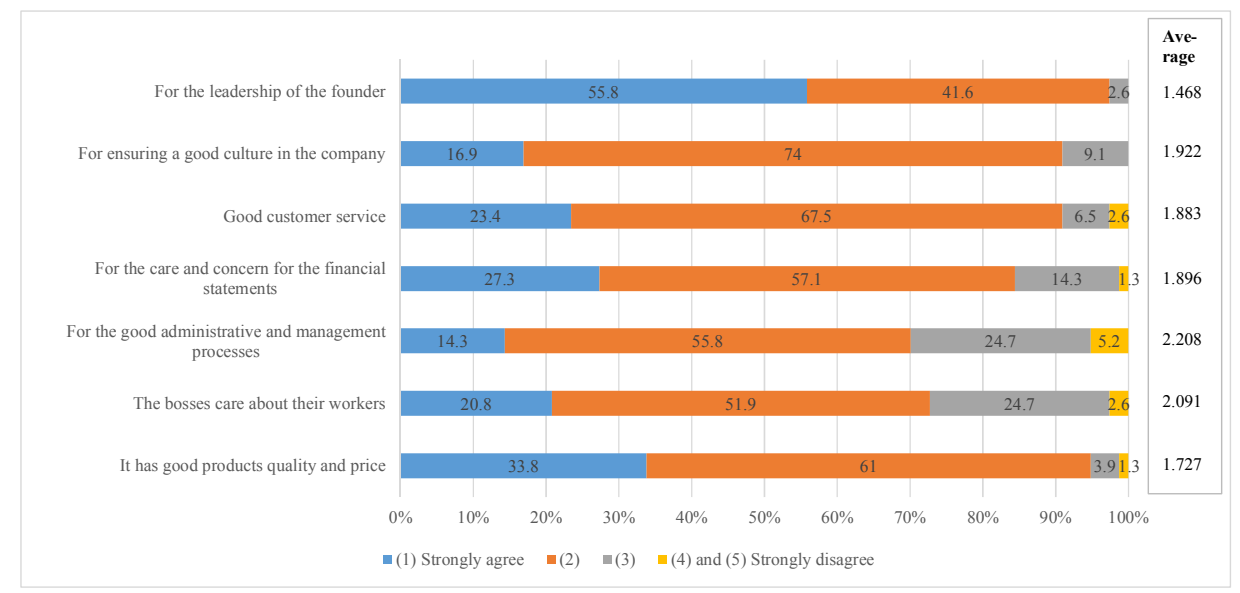

Source: Own elaboration

Table 4. Perception of the strategies implemented that would have allowed Arti S.A. to operate 70 years in the market (in \% of time working in the company of respondents)

\section{Rating scale \\ (in \% of respondents)}

\begin{tabular}{|c|c|c|c|c|c|c|c|}
\hline \multirow[b]{2}{*}{ Attribute } & \multicolumn{4}{|c|}{$\begin{array}{l}\text { Strongly } \\
\text { Strongly } \\
\text { agree }\end{array}$} & \multicolumn{3}{|c|}{ disagree } \\
\hline & $\begin{array}{c}\text { Time of } \\
\text { permanence } \\
\text { (years) }\end{array}$ & 1 & 2 & 3 & 4 & 5 & $\begin{array}{l}\text { Scale } \\
\text { Means }\end{array}$ \\
\hline \multirow{3}{*}{$\begin{array}{l}\text { Good products, quality } \\
\text { and price }\end{array}$} & 5 or less & 46.7 & 50 & & \multirow[t]{3}{*}{3.3} & & 1.599 \\
\hline & Between 6 a 15 & 20.8 & 66.7 & 12.5 & & & 1.917 \\
\hline & 16 and over & 30.4 & 69.6 & & & & 1.696 \\
\hline \multirow{3}{*}{$\begin{array}{l}\text { Bosses care about their } \\
\text { workers }\end{array}$} & 5 or less & 16.7 & 50 & 26.6 & \multirow[t]{3}{*}{6.7} & & 2.233 \\
\hline & Between 6 a 15 & 12.5 & 62.5 & 25 & & & 2.125 \\
\hline & 16 and over & 34.8 & 43.5 & 21.7 & & & 1.869 \\
\hline \multirow{2}{*}{$\begin{array}{l}\text { Good administrative and } \\
\text { management processes }\end{array}$} & 5 or less & 20 & 50 & 23.3 & 6.7 & & 2.167 \\
\hline & Between 6 a 15 & 4.2 & 54.1 & 37.5 & 4.2 & & 2.417 \\
\hline
\end{tabular}




\begin{tabular}{|c|c|c|c|c|c|c|}
\hline & 16 and over & 17.5 & 65.2 & 13 & 4.3 & 2.041 \\
\hline \multirow{3}{*}{$\begin{array}{l}\text { Care and concern for the } \\
\text { financial statements }\end{array}$} & 5 or less & 30 & 56.7 & 13.3 & & 1.833 \\
\hline & Between 6 a 15 & 12.5 & 66.7 & 20.8 & & 2.083 \\
\hline & 16 and over & 39.1 & 47.8 & 8.8 & 4.3 & 1.783 \\
\hline \multirow[t]{3}{*}{ Good customer service } & 5 or less & 23.3 & 66.7 & 6.7 & 3.3 & 1.900 \\
\hline & Between 6 a 15 & 25 & 62.5 & 8.3 & 4.2 & 1.917 \\
\hline & 16 and over & 21.7 & 74 & 4.3 & & 1.826 \\
\hline \multirow{3}{*}{$\begin{array}{l}\text { Ensuring a good culture } \\
\text { in the company }\end{array}$} & 5 or less & 16.7 & 70 & 13.3 & & 1.966 \\
\hline & Between 6 a 15 & 8.3 & 83.4 & 8.3 & & 2.000 \\
\hline & 16 and over & 26.1 & 69.6 & 4.3 & & 1.782 \\
\hline \multirow{3}{*}{$\begin{array}{l}\text { The leadership of the } \\
\text { founder }\end{array}$} & 5 or less & 53.3 & 40 & 6.7 & & 1.534 \\
\hline & Between 6 a 15 & 41.7 & 58.3 & & & 1.583 \\
\hline & 16 and over & 74 & 26.1 & & & 1.261 \\
\hline
\end{tabular}

Total: $100 \%$ horizontal

Source: Own elaboration

\section{DISCUSSION}

The success of Arti S.A. comes from the type of strong ethical leadership, the powerful religious values of the family Schreier Reck; mainly developed by the founder and also because of the company CEO and daughter, Annemarie Schreier who is a Lutheran pastor in Lima (Peru) which it means she has also deep beliefs both spiritual and religious ones; even more, all their values become and get to embed the organizational culture till a point where most people identify the company with the founder and her successor.

In a country where the cultural values are extremely traditional, following Hofstede's Culture Model (2011), as in Fig. 5 appear; the fact that the founder is a German immigrant woman gives to it the reason of being. The founder breaks most of the cultural tendencies of the country, she is a woman with a feminine way of behave and being while the country cultural values, following Hofstede model, are about $42 \%$ of masculinity weight. The profile of the 77 Arti S.A. employees who answered the survey is: $24.7 \%$ male and $75.3 \%$ female, so contrary to the cultural trend of the country, this company is a female company 
characterized. In addition to this, the founder, Eva Reck is near the workers while the power distance in the country has $64 \%$ of weight. Also, the company is 70 years old where long term orientation just rises the $25 \%$ of weight in the country. On the other hand, just indulgence which is under $50 \%$ of weight in the country could be in accordance with the paternalistic leadership of Eva Reck and the success of her leadership, following Mussolino and Calabrò (2014) about the successful benevolent and moral leadership style. And also her behaviour coincides with a low individualism as in the country $(16 \%)$.

Fig. 5: Type of Country Culture (6 dimensions Model)

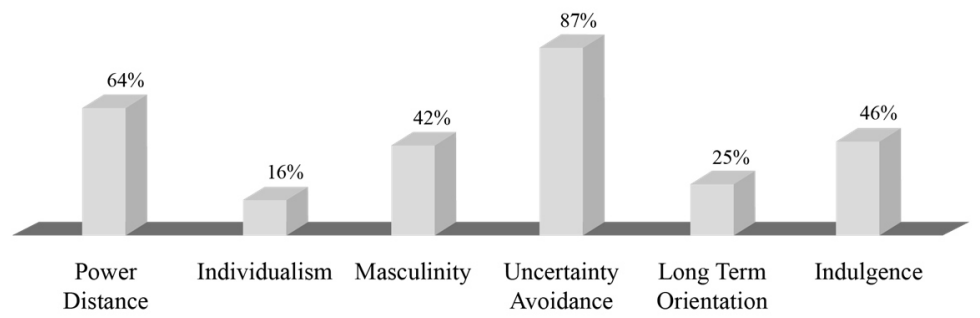

Source: Hofstede's Culture Model (2011)

Through the family conditions and antecedents, it is possible to check that the competitive advantage coming from this German family culture (SchreierReck) gave them the opportunity to became distributors of German products in Peru as unique ones, so, this chance placed the company in a very favourable starting position that later, and thanks to its Germanic mentality, high moral and ethical values caused it to remain a leader in its sector. Eva Reck was mainly the leader of it from the very beginning; there is a very important aspect in relation to this: is a woman who got Peru in the middle of twentieth century and in her situation it is possible to recognise some important aspects of her feminine ethical and religious leadership such as resilience, strong character, deep social and family commitment. On the other hand, it is important to show how the SEW promotes a CSR and BE instrumental ones; so, Arti S.A. shows this intrinsically because of business familiness and a narrow relationship between founder and other staff people and even the rest of the collaborators of the firm.

Arti S.A. has an organizational culture based on the religious family values. Specifically, Eva Reck ones, who is the Company's Founder. She has a strict 
commitment within the society which hosted her more than 70 years ago as a German immigrant after second world war. Ms Reck has strong religious believes inside the Calvinist ethics. This case study follows the Astrachan \& Zellweger's structure of family companies (2018) as shown in the Fig. 6. The family are the owners, they have the power of the company, the founder and the CEO, mother and daughter, they are everyday in the business working and supervising everything. Even more, there is a clear overlap between the family and business values, the most illustrative example is the "Ora et Labora" that presides over the organization.

Fig. 6: Sub-dimensions of F-PEC as performance antecedents (in accordance to Astrachan et al. 2002):

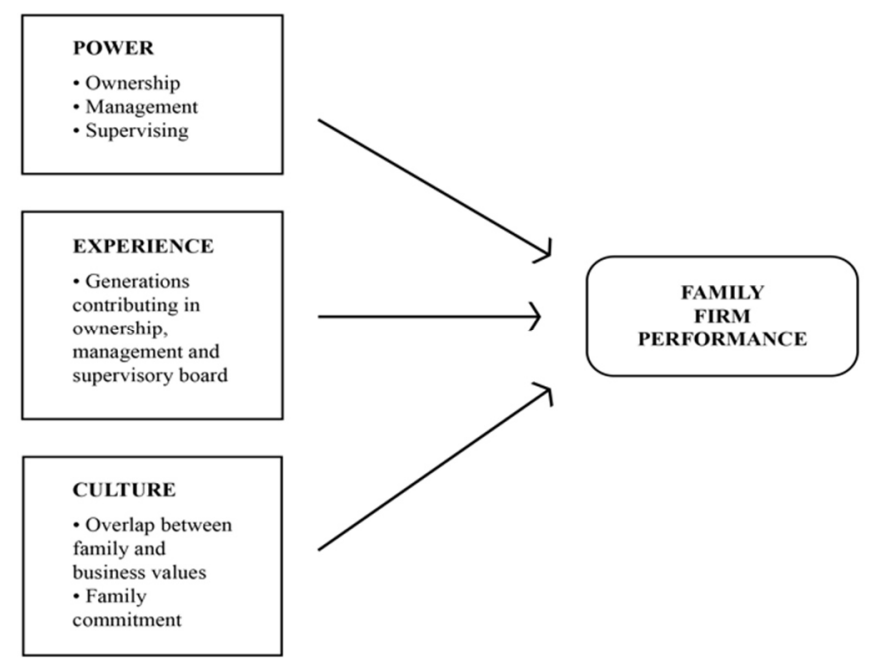

Source: Astrachan \& Zellweger, 2008

The Company's motto which is just in the front door of the company shows the philosophy and aim of this feminine family business: "Ora et Labora" this Latin sentence which in English means: "Pray and Work" is the aim of the Company's philosophy. So that is mean: individual presence and family and company resilience (Weber, 1986). 


\section{CONCLUSIONS}

The analysed organization can be considered as a model of successful small feminine family company in the Peruvian market with a female entrepreneur/ founder and female successor, something really new and special (Mustapha, 2016). The main keys of its permanence in this emergent economy are based on an ethical organizational culture. In particular, those values which are in relation to the Lutheran religion and moral, contributes to forming the foundations and guidelines from which the organization is managed. This powerful religious leadership determines the way of working in the company. In this way the firm shows that the asset of its 70 years is due to the strong, close and kind figure of its founder and leader. She has defined the way of work and the values from which the company operates, a way which is followed by the company CEO, her daughter and successor. We conclude that this is a precise wealthy business ideal with specific cultural values and features, mainly the stewardship of the founder and owner, the familiness of the organization, the Calvinist performance, sacrifice, hard work and high social commitment. Even more, this style gives as a result that there are more women than men working in the company and something which is the most important, the consequence is a competitive and resilience business.

What workers recognize most as positive is the close and familiar treatment and what they also point out as something negative is the low salary, however they feel comfortable with the company. This is evidenced by people who have been working in the company for more than 15 years. Although currently in Peru, new generations such as the Gen $\mathrm{Z}$, for example, prefer to change companies quickly, it is observed that there are also young people, under 30 years, who feel comfortable working in the company. Women are the majority of people inside the company and they are significantly more critical than other workers.

The leadership has been fundamental for the success of the company and this is clearly influenced in the very marked Lutheran culture: frugality, hard work, austerity, quality in the product, but also the desire to share with the collaborators when there are triumphs Pray and work. It is important to highlight that phrase as a maxim that every worker has in the company.

It should be noted that the formation of the founder's daughter, as successor and CEO of the company, has been very important the way in which the founder was training her. She has been working in the company for 25 years, learned from below, went through all the positions and was learning in practice. Annie has remained firm in the main values of the company, such as teamwork, 
discipline, austerity, concern for the welfare of staff and culture. But in addition to this has been able to combine with new components such as innovation, creativity, etc. It is important to note that Annemarie is a Lutheran Pastor in Lima, an active committed believer in her community, recognized by the people; vital, cheerful and hard-working, she has inherited the spirit of her mother and of the company.

The emotional salary is interesting in the relationship of company and collaborator. They have some interesting practices but the most relevant is the good treatment of the bosses with workers, the concern for their workers and their families, this is evidenced in the issue of the loans of money for personal issues to their workers, for example, in addition of other practices where there is evidence of concern for their worker.

In relation to the company's leadership it is confirmed that family, religious and ethical businesses have a greater commitment to workers, specifically in relation to job stability, high satisfaction, close relationships and authentic communication in the sense spoken by Paul Watzlawick et al. (2011). There is a high commitment to the society in which the company is installed, with respect to the environment, the quality of the products, good financial statements. Leader features demonstrate that there is a high involvement with the aspects of the Fig. 7.

Fig. 7: Company's survival dimensions

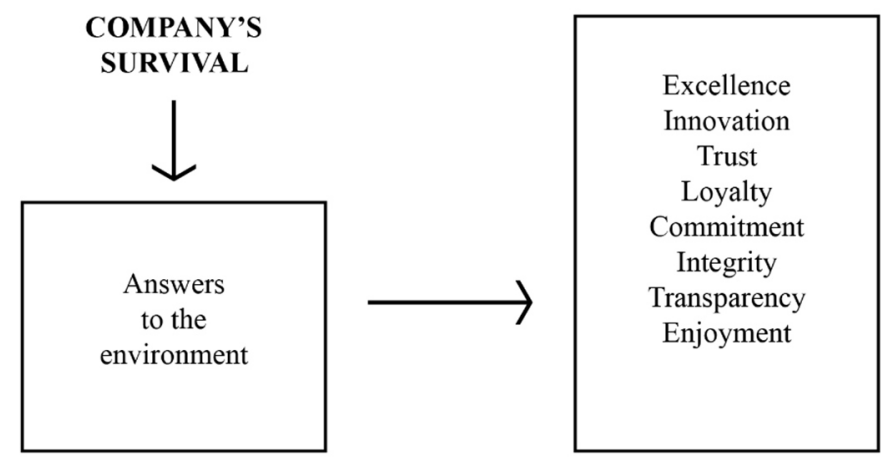

Source: own elaboration 
This research shows a model of feminine, family, successful business. The wealth of Lutheran religious and ethical values to the long-term survival of this kind of companies and how the aim and character of the leader is a relevant factor for the future of the successors, staff and the company as a whole.

\section{REFERENCES}

Aguilar, A., \& Galindo, R. (2014). El ejecutivo espartano. Lima: Grupo Editorial Mesa Redonda S.A.C ISBN: 9788793412217

Antares, A. (2013). Interdependencia entre el liderazgo transformacional, cultura organizacional y cambio educativo: Una reflexión. REICE, (11)1, pp. 73-91 ISSN: $1696-4713$

Anzola, O (2003) Una mirada a la cultura corporativa. Bogotá: Universidad Externado de Colombia. ISBN: 9789586167451

Astrachan, C. B., Botero, I., Astrachan, J. H., \& Prügl, R. (2018). Branding the family firm: A review, integrative framework proposal, and research agenda. Journal of Family Business Strategy. DOI: 10.1016/j.jfbs.2018.01.002

Bammens, Y., Notelaers, G., \& Van Gils, A. (2015). Implications of family business employment for employees' innovative work involvement. Family Business Review, 28(2), 123-144. DOI: 10.1177/0894486513520615

Borjas, L. (2010). Cultura y liderazgo en una empresa de servicios venezolana. ANALES, (10)1, pp. 139-162. ISSN: 0120-4645

Calvo, J. (2012). La oreja en el piso. Lima: Aguilar. ISBN 978-9972848995

Cantillo, G., \& Daza, J. (2011). Influencia de la Cultura Organizacional en la Competitividad de las Empresas. Escenarios, (9)1, pp. 18-23.

Copeland, M. K. (2016). The impact of authentic, ethical, transformational leadership on leader effectiveness. Journal of Leadership, Accountability and Ethics, 13(3), 79.

Cortina, A. (1994). Ética de la empresa: claves para una nueva cultura empresarial, Madrid: Tecnos. ISBN 8481640131, 9788481640137

Costa, J. (2012). El DirCom hoy. Barcelona: Costa Punto Com ISBN/ISSN/DL:9 78-84-612-6816-0

Cruz, N. M., Contreras, I. B., \& Barahona, J. H. (2014). La" familiaridad dinámica" de las empresas familiares. El caso del Grupo Yllera. Universia Business Review, 2(42). ISSN: 1698-5117

Cummings, T. G., \& Worley, C. G. (2014). Organization development and change. Cengage learning. ISBN 13: 978-0-324-42138-5

Faraudello, A., \& Songini, L. (2018). Women's Role in Family Business: Evolution and Evidences from a European Case Study. Journal of Modern 
Accounting and Auditing, 14(2), 70-89. DOI: 10.17265/1548-6583/2018. 02.003

Frank, H., Kessler, A., Rusch, T., Suess-Reyes, J., \& Weismeier-Sammer, D. (2017). Capturing the familiness of family businesses: Development of the family influence familiness scale (FIFS). Entrepreneurship Theory and Practice, 41(5), 709-742. DOI: 10.1111/etap.12229

Giménez, J., Jiménez, D., \& Martínez, M. (2014). La gestión de calidad: importancia de la cultura organizativa para el desarrollo de variables intangibles. Revista Europea de Dirección y Economía de la Empresa, (23), pp.115-126. https://doi.org/10.1016/j.redee.2014.02.002

Gomez-Mejia, L. R., Campbell, J. T., Martin, G., Hoskisson, R. E., Makri, M., \& Sirmon, D. G. (2014). Socioemotional wealth as a mixed gamble: revisiting family firm R \& D investments with the behavioral agency model. Entrepreneurship Theory and Practice, 38(6), 1351-1374. DOI: 10.1111/ etap. 12083

Gonzáles, J., \& Parra, C. (2008). Caracterización de la cultura organizacional. Clima organizacional, motivación, liderazgo y satisfacción de las pequeñas empresas del Valle de Sugamuxi y su incidencia en el espíritu empresarial. Pensamiento \& gestión, (25), pp. 40-57. ISSN electrónico: 2145-941X

Guillezeau, P. (1999). La cultura organizacional en el desarrollo en el desarrollo de empresas inteligentes. Fundamentos: valores, comunicación y liderazgo. Telos, (1)2, pp. 221-232. ISSN electrónico: 2145-941X

Hofstede, G. (2011). Dimensionalizing cultures: The Hofstede model in context. Online readings in psychology and culture, 2(1), 8. https://doi.org/10.9707/ 2307-0919.1014

Hoobler, J. M., Masterson, C. R., Nkomo, S. M., \& Michel, E. J. (2018). The business case for women leaders: Meta-analysis, research critique, and path forward. Journal of Management, 44(6), 2473-2499. https://doi.org/10.1177/ 0149206316628643

Hoyt, C. L., \& Murphy, S. E. (2016). Managing to clear the air: Stereotype threat, women, and leadership. The Leadership Quarterly, 27(3), 387-399.

Kenyon-Rouvinez, D. (2017). Secrets of success in long-lasting family firms. Perspectives for Managers, (193).

Lehrke, A. S., \& Sowden, K. (2017). Servant Leadership and Gender. In Servant Leadership and Followership (pp. 25-50). Palgrave Macmillan, Cham. DOI: 10.1108/LODJ-02-2015-0019\}

Lussier, R., \& Achua, C. (2016). Liderazgo: teoría, aplicación y desarrollo de habilidades, . México: Cengage Learning Editores. ISBN: 9786075190693

Madison, K., Holt, D. T., Kellermanns, F. W., \& Ranft, A. L. (2016). Viewing family firm behavior and governance through the lens of agency and 
stewardship theories. Family Business Review, 29(1), 65-93. https://doi.org/ $10.1177 / 0894486515594292$

Meens, B., \& Molinaro, V. (2016). Driving Organizational Transformation Through Strong Leadership Accountability: It's Time for HR Leaders to Step Up. People and Strategy, 39(3), 28. ISSN: 1946-4606

Mussolino, D., \& Calabrò, A. (2014). Paternalistic leadership in family firms: Types and implications for intergenerational succession. Journal of Family Business Strategy, 5(2), 197-210. https://doi.org/10.1016/j.jfbs.2013.09.003

Mustapha, M. (2016). Challenges and success factors of female entrepreneurs: Evidence from a developing country. International Review of Management and Marketing, 6(4S), 224-231. ISSN: 2146-4405

Neubaum, D. O., Thomas, C. H., Dibrell, C., \& Craig, J. B. (2017). Stewardship climate scale: An assessment of reliability and validity. Family Business Review, 30(1), 37-60. https://doi.org/10.1177/0894486516673701

Neubauer, F., \& Lank, A. G. (2016). The family business: Its governance for sustainability. Springer. ISBN 1349144657, 9781349144655

Northouse, P. G. (2018). Leadership: Theory and practice. Sage publications. ISBN 1-4129-4161-X

Politis, J. D., \& Politis, D. J. (2018). Examination of the relationship between servant leadership and agency problems: gender matters. Leadership \& Organization Development Journal, 39(2), 170-185. https://doi.org/10.1108/ LODJ-01-2016-0020

Ramadani V., Hoy F. (2015) Context and Uniqueness of Family Businesses. In: Dana LP., Ramadani V. (eds) Family Businesses in Transition Economies. Springer, Cham https://doi.org/10.1007/978-3-319-14209-8_2

Ramírez, J. (2017). Una voz que cambia vidas: Campañas de responsabilidad social en la radio: el caso de RPP Noticias. Lima: Fondo Editorial de la Universidad de Lima. ISBN: 978-9972-45-386-1

Rau, S. B., Astrachan, J. H., \& Smyrnios, K. X. (2018). The F-PEC revisited: From the family business definition dilemma to foundation of theory. Family Business Review, 31(2), 200-213. https://doi.org/10.1177/0894486518778 172

Ramos, H. M., Man, T. W. Y., Mustafa, M., \& Ng, Z. Z. (2014). Psychological ownership in small family firms: Family and non-family employees' work attitudes and behaviours. Journal of Family Business Strategy, 5(3), 300-311. https://doi.org/10.1016/j.jfbs.2014.04.001

Sadowsky, J., \& Roche, L. (2013). Las siete reglas del storytelling. Buenos Aires: Ediciones Granica S.A. ISBN 9506417512,9789506417512

Sanagustín-Fons, M.V. (2011) Valores y ética empresarial. Un enfoque sociológico. Madrid: Trotta. ISBN: 978-84-9879-231-7 
Sheen, R. (2016). La cultura organizacional y su impacto en la gestión empresarial. Lima: Universidad de Lima ISBN 978-9972-45-352-6

Scheler, M. (2003). Gramática de los sentimientos: lo emocional como fundamento de la ética. Barcelona: Crítica. ISBN: 9788484324157

Torres, M., \& Ortiz, C. (2006). El Liderazgo Transformacional, Dimensiones e Impacto en la Cultura Organizacional y Eficacia de las Empresas. Revista Facultad de Ciencias Económicas: Investigación y Reflexión, (14)1, pp. 118134 ISSN 0121-6805

Watzlawick, P., Bavelas, J. B., \& Jackson, D. D. (2011). Pragmatics of human communication: A study of interactional patterns, pathologies and paradoxes. WW Norton \& Company. ISBN 0393707075, 9780393707076

Xu, L., Stewart, T., \& Haber-Curran, P. (2015). Measurement invariance of the Servant Leadership Questionnaire across K-12 principal gender. School Leadership \& Management, 35(2), 202-214. https://doi.org/10.1080/136324 34.2015.1010502

Zientara, P. (2017). Socioemotional wealth and corporate social responsibility: A critical analysis. Journal of Business Ethics, 144(1), 185-199. https://doi.org/ 10.1007/s10551-015-2848-1

María Victoria Sanagustin Fons Facultad Empresa y Gestión Pública Universidad de Zaragoza Campus de Huesca, Plaza de la Constitución s/n 22001 Huesca (España) https://orcid.org/0000-0002-3957-2466

Julianna Paola Ramírez-Lozano CENTRUM Católica Graduate Business School Pontificia Universidad Católica del Perú Jirón Daniel Alomía Robles 125 Urbanización Los Álamos de Monterrico- Surco 15023 Lima (Perú) https://orcid.org/0000-0001-8749-6915

Renato Peñaflor-Guerra Universidad Peruana de Ciencias Aplicadas (UPC)

Facultad de Comunicaciones Carrera de Comunicaciones e Imagen empresarial Prolongación Primavera 2390 Urbanización Los Álamos de Monterrico- Surco 15023 


\section{ANNEX I: SURVEY TO ARTI S.A. COMPANY COLLABORATORS}

The present survey is anonymous. We appreciate your honest participation in each of the following questions.

1. Sex (check one option)
a. Man
b. Woman

2. Area of the company where you work:

3. How old are you? (check an option)
a. Between 18 and 25 years old old
b. Between 36 and 45 years old
c. Between 36 and 45 years
d. More than 46 years old

4. How long have you been working for the company? (check an option)
a. Less than a year
b. Between 1 and 5 years old
c. Between 6 and 15 years
d. Between 16 and 20 years
e. Between 21 and 30 years
f. More than 31 years

5. Do you know the founder? (check an option)
a. Yes
b. No

6. Do you consider the company Arti S.A. a good place to work? (check an option)
a. Yes
b. No

Why:

7. In regards to your relationship with the company Arti S.A. (check one option in each case)

\begin{tabular}{|l|l|l|l|l|l|}
\hline & $\begin{array}{l}\text { Strongly } \\
\text { agree }\end{array}$ & Agree & $\begin{array}{l}\text { Neither } \\
\text { agree nor } \\
\text { disagree }\end{array}$ & Disagree & $\begin{array}{l}\text { Strongly } \\
\text { disagree }\end{array}$ \\
\hline $\begin{array}{l}\text { I feel that the } \\
\text { relationship with my } \\
\text { boss is friendly }\end{array}$ & & & & & \\
\hline
\end{tabular}




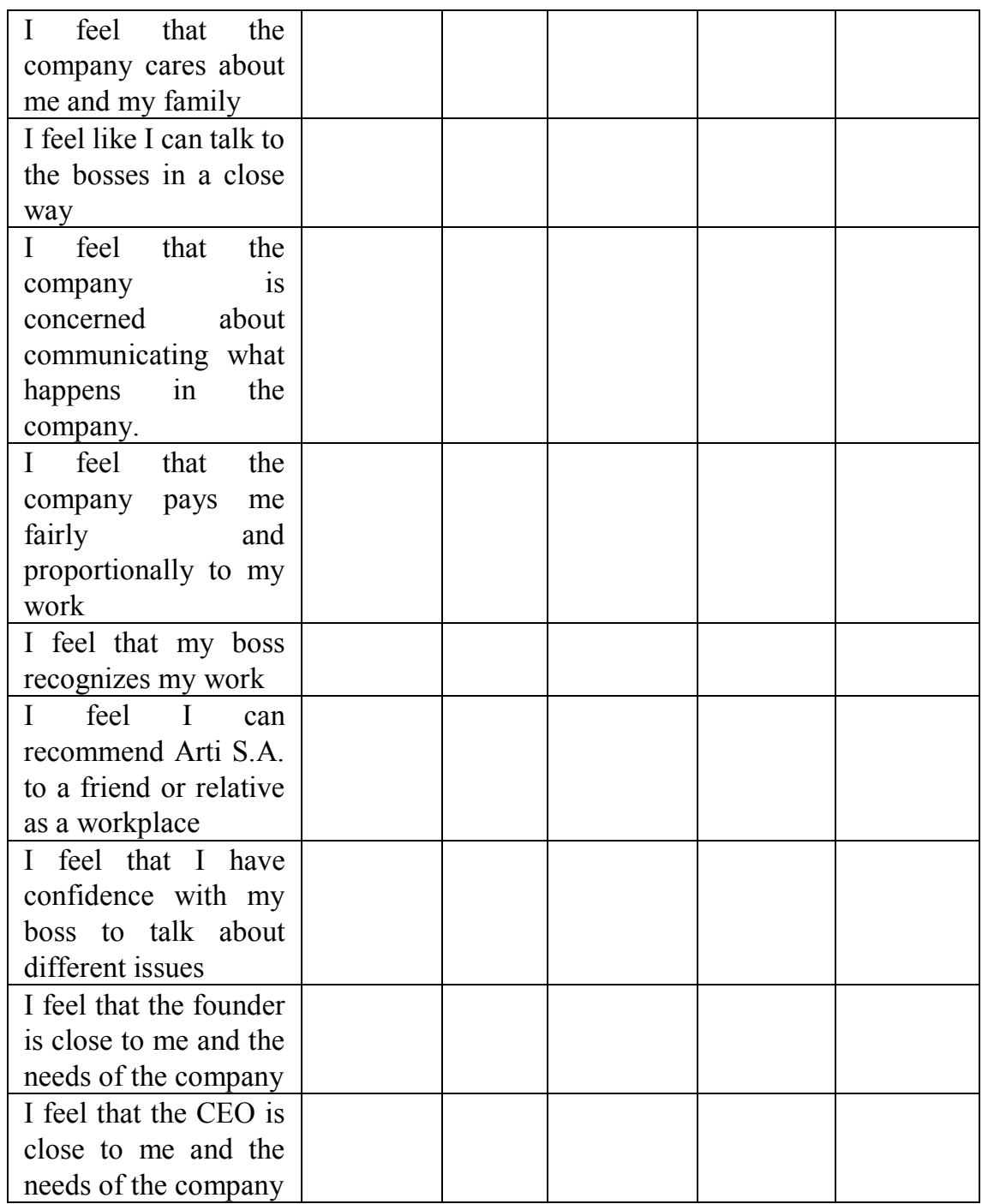


8. In regards to your work at the Arti S.A. company, indicate your satisfaction on the following topics: (check one option in each case)

\begin{tabular}{|c|c|c|c|c|c|}
\hline & $\begin{array}{l}\text { Very } \\
\text { Satiefied }\end{array}$ & Satisfied & $\begin{array}{l}\text { Neither } \\
\text { satisfied } \\
\text { nor } \\
\text { disatisfied }\end{array}$ & Disatisfied & $\begin{array}{l}\text { Very } \\
\text { Disatisfied }\end{array}$ \\
\hline $\begin{array}{l}\text { With work } \\
\text { schedules }\end{array}$ & & & & & \\
\hline $\begin{array}{l}\text { With the } \\
\text { rules and } \\
\text { regulations }\end{array}$ & & & & & \\
\hline $\begin{array}{l}\text { With my } \\
\text { benefits as an } \\
\text { employee }\end{array}$ & & & & & \\
\hline $\begin{array}{l}\text { With the } \\
\text { benefits for } \\
\text { my family }\end{array}$ & & & & & \\
\hline $\begin{array}{l}\text { With the } \\
\text { uniform that } \\
\text { I use daily }\end{array}$ & & & & & \\
\hline $\begin{array}{l}\text { With the } \\
\text { facilities and } \\
\text { offices }\end{array}$ & & & & & \\
\hline $\begin{array}{l}\text { With the } \\
\text { salary }\end{array}$ & & & & & \\
\hline $\begin{array}{l}\text { With the } \\
\text { amount of } \\
\text { work that I } \\
\text { perform }\end{array}$ & & & & & \\
\hline $\begin{array}{l}\text { With the } \\
\text { treatment } \\
\text { received } \\
\text { from my } \\
\text { bosses }\end{array}$ & & & & & \\
\hline $\begin{array}{l}\text { With the } \\
\text { treatment of } \\
\text { my co- } \\
\text { workers }\end{array}$ & & & & & \\
\hline
\end{tabular}


9. What actions or strategies do you consider the Arti S.A. company has achieved enduring 70 years in the market? (check one option in each case)

\begin{tabular}{|l|l|l|l|l|l|}
\hline & $\begin{array}{l}\text { Strongly } \\
\text { agree }\end{array}$ & Agree & $\begin{array}{l}\text { Neither } \\
\text { agree } \\
\text { nor } \\
\text { disagree }\end{array}$ & Disagree & $\begin{array}{l}\text { Strongly } \\
\text { disagree }\end{array}$ \\
\hline $\begin{array}{l}\text { It has good products } \\
\text { quality and price }\end{array}$ & & & & & \\
\hline $\begin{array}{l}\text { The bosses care } \\
\text { about their workers }\end{array}$ & & & & & \\
\hline $\begin{array}{l}\text { For the good } \\
\text { administrative and } \\
\text { management } \\
\text { processes }\end{array}$ & & & & & \\
\hline $\begin{array}{l}\text { For the care and } \\
\text { concern for the } \\
\text { financial statements }\end{array}$ & & & & & \\
\hline $\begin{array}{l}\text { Good customer } \\
\text { service }\end{array}$ & & & & & \\
\hline $\begin{array}{l}\text { For ensuring a good } \\
\text { culture in the } \\
\text { company }\end{array}$ & & & & & \\
\hline $\begin{array}{l}\text { For the leadership of } \\
\text { the founder }\end{array}$ & & & & & \\
\hline
\end{tabular}




\section{Annex I: T-Test Results (Perception Attributes; Question 7)}

\begin{tabular}{|c|c|c|c|c|c|c|}
\hline & РЕRСЕРТОYS & MFDIA & ERROR & T- & PYHF & \begin{tabular}{|r} 
CON \\
INTERV
\end{tabular} \\
\hline & & & DEVIATION & & & Lower \\
\hline & P07_2:I feel that the company cares about me and my family & -0.558 & 0.133 & -4.188 & 0.002 & -0.987 \\
\hline & P07 $3:$ I feel like I can talk to the bosses in a close way & -0.325 & 0.113 & -2.877 & 0.123 & -0.688 \\
\hline & P07 $4:$ I feel that the company is concemed about conmunicating what happens in the conpany & -0.558 & 0.118 & -4.717 & 0.000 & -0.939 \\
\hline hat & P07_5: Siento que la empresa me paga de manera justa y proporcional a mi trabajo & -1.104 & 0.131 & -8.419 & 0.000 & -1.526 \\
\hline relationship with my boss & P07_6: I feel that my boss recognizes my work & -0.377 & 0.113 & -3.334 & 0.035 & -0.740 \\
\hline & P07 7 : I feel I can recommend ARTI to a friend or relative as a workplace & -0.987 & 0.124 & -7.963 & 0.000 & -1.386 \\
\hline & P07_8: I feel that I have confidence with my boss to talk about different issues & -0.403 & 0.126 & -3.202 & 0.052 & -0.807 \\
\hline & P07-9: I feel that the founder is close to me and the needs of the company & -0.338 & 0.122 & -2.760 & 0.162 & -0.731 \\
\hline & P07_-10:I feel that the CEO is close to me and the needs of the company & -0.338 & 0.124 & -2.729 & 0.174 & -0.736 \\
\hline & P07 1 : I feel that the relationship with my boss is firiendly & 0.558 & 0.133 & 4.188 & 0.002 & 0.130 \\
\hline & P07 $3:$ I feel like I can talk to the bosses in a close way & 0.234 & 0.140 & 1.670 & 0.811 & -0.217 \\
\hline & P07- 4 : I feel that the company is concemed about conmunicating what happens in the company & 0.000 & 0.144 & 0.000 & 1.000 & -0.464 \\
\hline & P07_5: Siento que la empresa me paga de manera justa y proporcional a mi trabajo & -0.545 & 0.155 & -3.513 & 0.020 & -1.044 \\
\hline company cares about me & P07_6: I feel that my boss recognizes my work & 0.182 & 0.140 & 1.298 & 0.953 & -0.269 \\
\hline and $\mathrm{my}$ family & P07_ 7 : I feel I can recommend ARTI to a friend or relative as a workplace & -0.429 & 0.149 & -2.877 & 0.122 & -0.908 \\
\hline & P07 $8:$ I feel that I have confidence with my boss to talk about different issues & 0.156 & 0.151 & 1.035 & 0.990 & -0.328 \\
\hline & P07_9: I feel that the founder is close to me and the needs of the company & 0.221 & 0.148 & 1.494 & 0.893 & -0.254 \\
\hline & P07 10 : I feel that the CEO is close to me and the needs of the company & 0.221 & 0.149 & 1.483 & 0.898 & -0.258 \\
\hline & P07_ $1: 1$ feel that the relationship with my boss is fririendly & 0.325 & 0.113 & 2.877 & 0.123 & -0.038 \\
\hline & P07 2:I feel that the company cares about me and my family & -0.234 & 0.140 & -1.670 & 0.811 & -0.684 \\
\hline & PO7 $4:$ : I feel that the company is concemed about conmunicating what happens in the company & -0.234 & 0.126 & -1.857 & 0.699 & -0.639 \\
\hline P07_ 3: I feel like I can talk & P07 5 : I feel that the company pays me fairly and proportionally to my work & -0.779 & 0.138 & -5.639 & 0.000 & -1.223 \\
\hline $\begin{array}{l}\text { to the bosses in a close } \\
\text { the }\end{array}$ & P07_6: I feel that my boss recognizes my work & -0.052 & 0.121 & -0.429 & 1.000 & -0.441 \\
\hline & P07_7 : I feel I can recommend ARTI to a friend or relative as a workplace & -0.662 & 0.131 & -5.040 & 0.000 & -1.084 \\
\hline & P07_ 8 : I feel that I have confidence with my boss to talk about different issues & -0.078 & 0.133 & -0.586 & 1.000 & -0.506 \\
\hline & P07 9 : I feel that the founder is close to me and the needs of the company & -0.013 & 0.130 & -0.100 & 1.000 & -0.430 \\
\hline & P07 $10:$ I feel that the CEO is close to me and the needs of the company & -0.013 & 0.131 & -0.099 & 1.000 & -0.435 \\
\hline & P07_ 1 : I feel that the relationship with $m y$ boss is fritiendly & 0.558 & 0.118 & 4.717 & 0.000 & 0.178 \\
\hline & P07_2: I feel that the company cares about me and my family & 0.000 & 0.144 & 0.000 & 1.000 & -0.464 \\
\hline & P07_3 : I feel like I can talk to the bosses in a close way & 0.234 & 0.126 & 1.857 & 0.699 & -0.171 \\
\hline P07_ 4 : I feel that the & P07_5: I feel that the company pays me fairly and proportionally to my work & -0.545 & 0.143 & -3.824 & 0.007 & -1.003 \\
\hline concerned & P07_6: I feel that my boss recognizes my work & 0.182 & 0.126 & 1.443 & 0.912 & -0.223 \\
\hline $\begin{array}{l}\text { about communicicating what } \\
\text { happens in the company }\end{array}$ & P07_7 : I feel I can recommend ARTI to a friend or relative as a workplace & -0.429 & 0.136 & -3.156 & 0.059 & -0.865 \\
\hline & P07 $8:$ I feel that I have confidence with my boss to talk about different issues & 0.156 & 0.138 & 1.133 & 0.981 & -0.286 \\
\hline & P07 $9:$ I feel that the founder is close to me and the needs of the company & 0.221 & 0.135 & 1.642 & 0.826 & -0.211 \\
\hline & P07 10 : I feel that the CEO is close to me and the needs of the company & 0.221 & 0.136 & 1.627 & 0.834 & -0.216 \\
\hline & P07_ 1 : I feel that the relationship with my boss is frriendly & 1.104 & 0.131 & 8.419 & 0.000 & 0.682 \\
\hline & P07_2:I feel that the company cares about me and my family & 0.545 & 0.155 & 3.513 & 0.020 & 0.047 \\
\hline & P07 3: I feel like I can talk to the bosses in a close way & 0.779 & 0.138 & 5.639 & 0.000 & 0.335 \\
\hline P07_5: I feel that the & P07-4: I feel that the company is concerned about communicating what happens in the company & 0.545 & 0.143 & 3.824 & 0.007 & 0.088 \\
\hline company pays me fairly & P07_6: I feel that my boss recognizes my work & 0.727 & 0.138 & 5.260 & 0.000 & 0.283 \\
\hline & P07_ 7 : I feel I can recommend ARTI to a friend or relative as a workplace & 0.117 & 0.147 & 0.795 & 0.999 & -0.356 \\
\hline & P07 8: I feel that I have confidence with my boss to talk about different issues & 0.701 & 0.149 & 4.709 & 0.000 & 0.223 \\
\hline & P07 9 : I feel that the founder is close to me and the needs of the conpany & 0.766 & 0.146 & 5.246 & 0.000 & 0.297 \\
\hline & P07 10 : I feel that the CEO is close to me and the needs of the company & 0.766 & 0.147 & 5.205 & 0.000 & 0.294 \\
\hline & P07 1: I feel that the relationship with my boss is firiendly & 0.377 & 0.113 & 3.334 & 0.035 & 0.013 \\
\hline & $\mathrm{P} 07-2:$ I feel that the company cares about me and my family & -0.182 & 0.140 & -1.298 & 0.953 & -0.633 \\
\hline & P07 $3:$ I feel like I can talk to the bosses in a close way & 0.052 & 0.121 & 0.429 & 1.000 & -0.337 \\
\hline & P07 4 : I feel that the company is concerned about conmunicating what happens in the company & -0.182 & 0.126 & -1.443 & 0.912 & -0.587 \\
\hline P07_6: I feel that my boss & P07_5: I feel that the company pays me fairly and proportionally to my work & -0.727 & 0.138 & -5.260 & 0.000 & -1.171 \\
\hline & P07 7 : I feel I can recommend ARTI to a friend or relative as a workplace & -0.610 & 0.131 & -4.642 & 0.000 & -1.033 \\
\hline & P07 8 : I feel that I have confidence with my boss to talk about different issues & -0.026 & 0.133 & -0.195 & 1.000 & -0.454 \\
\hline & P07 9 : I feel that the founder is close to me and the needs of the company & 0.039 & 0.130 & 0.300 & 1.000 & -0.379 \\
\hline & $\mathrm{P} 07-10$ : I feel that the $\mathrm{CBO}$ is close to me and the needs of the company & 0.039 & 0.131 & 0.297 & 1.000 & -0.383 \\
\hline & P07 $1:$ I feel that the relationship with my boss is friendly & 0.987 & 0.124 & 7.963 & 0.000 & 0.588 \\
\hline & $\mathrm{P} 072$ : I feel that the company cares about me and my family & 0.429 & 0.149 & 2.877 & 0.122 & -0.050 \\
\hline & P07 $3:$ I feel like I can talk to the bosses in a close way & 0.662 & 0.131 & 5.040 & 0.000 & 0.240 \\
\hline & P07 $4:$ I feel that the company is concerned about communicating what happens in the company & 0.429 & 0.136 & 3.156 & 0.059 & -0.008 \\
\hline company care & P07 $5:$ : feel that the company pays me fairly and proportionally to my work & -0.117 & 0.147 & -0.795 & 0.999 & -0.590 \\
\hline and my family & P07_6: I feel that my boss recognizes my work & 0.610 & 0.131 & 4.642 & 0.000 & 0.188 \\
\hline & P07 8 : I feel that I have confidence with my boss to talk about different issues & 0.584 & 0.143 & 4.096 & 0.003 & 0.127 \\
\hline & P07 $9:$ I feel that the founder is close to me and the needs of the company & 0.649 & 0.140 & 4.649 & 0.000 & 0.201 \\
\hline & $\begin{array}{l}\text { P07 } 10: I \text { feel that the CEO is close to me and the needs of the company }\end{array}$ & 0.649 & 0.141 & 4.609 & 0.000 & 0.197 \\
\hline & P07_ 1 : I feel that the relationship with my boss is firiendly & 0.403 & 0.126 & 3.202 & 0.052 & -0.002 \\
\hline & P07_2:I feel that the company cares about me and my family & -0.156 & 0.151 & -1.035 & 0.990 & -0.640 \\
\hline & P07 $3:$ I feel like I can talk to the bosses in a close way & 0.078 & 0.133 & 0.586 & 1.000 & -0.350 \\
\hline el that thave & P07 4 : I feel that the company is concerned about communicating what happens in the company & -0.156 & 0.138 & -1.133 & 0.981 & -0.598 \\
\hline ewith my boss & P07 $5:$ : f feel that the company pays me fairly and proportionally to my work & -0.701 & 0.149 & -4.709 & 0.000 & -1.179 \\
\hline & P07 6: I feel that my boss recognizes my work & 0.026 & 0.133 & 0.195 & 1.000 & -0.402 \\
\hline & P07_7: I feel I can recommend ARTI to a friend or relative as a workplace & -0.584 & 0.143 & -4.096 & 0.003 & -1.042 \\
\hline & P07 $9:$ I feel that the founder is close to me and the needs of the company & 0.065 & 0.141 & 0.460 & 1.000 & -0.389 \\
\hline & P07_10:I feel that the CEO is close to me and the needs of the company & 0.065 & 0.142 & 0.456 & 1.000 & -0.393 \\
\hline & P07_ $1:$ I feel that the relationship with my boss is fririendly & 0.338 & 0.122 & 2.760 & 0.162 & -0.056 \\
\hline & $\mathrm{P} 072:$ I feel that the company cares about me and my family & -0.221 & 0.148 & -1.494 & 0.893 & -0.696 \\
\hline & P07 $3:$ I feel like I can talk to the bosses in a close way & 0.013 & 0.130 & 0.100 & 1.000 & -0.404 \\
\hline & P07 $4:$ I feel that the company is concerned about communicating what happens in the company & -0.221 & 0.135 & -1.642 & 0.826 & -0.653 \\
\hline $\begin{array}{l}\text { Pot 9: Ifeel that the } \\
\text { founder is close to me and }\end{array}$ & P07 $5:$ : f feel that the company pays me fairly and proportionally to my work & -0.766 & 0.146 & -5.246 & 0.000 & -1.235 \\
\hline the needs of the company & P07 6: I feel that my boss recognizes my work & -0.039 & 0.130 & -0.300 & 1.000 & -0.457 \\
\hline & P07_ 7 : I feel I can recommend ARTI to a friend or relative as a workplace & -0.649 & 0.140 & -4.649 & 0.000 & -1.098 \\
\hline & P07 8: I feel that I have confidence with my boss to talk about different issues & -0.065 & 0.141 & -0.460 & 1.000 & -0.519 \\
\hline & P07_10:I feel that the CBO is close to me and the needs of the company & 0.000 & 0.140 & 0.000 & 1.000 & -0.448 \\
\hline & P07_ $1:$ I feel that the relationship with my boss is frriendly & 0.338 & 0.124 & 2.729 & 0.174 & -0.061 \\
\hline & $\mathrm{P} 072:$ I feel that the company cares about me and my family & -0.221 & 0.149 & -1.483 & 0.898 & -0.700 \\
\hline & P07 3 : I feel like I can talk to the bosses in a close way & 0.013 & 0.131 & 0.099 & 1.000 & -0.409 \\
\hline P07 10 . Ifeel that the $\mathrm{C}$ ( & P07 $4:$ I feel that the company is concerned about communicating what happens in the conpany & -0.221 & 0.136 & -1.627 & 0.834 & -0.657 \\
\hline & P07 5: I feel that the company pays me fairly and proportionally to my work & -0.766 & 0.147 & -5.205 & 0.000 & -1.239 \\
\hline needs of the company & P07 6: I feel that my boss recognizes my work & -0.039 & 0.131 & -0.297 & 1.000 & -0.461 \\
\hline & P07_7 : I feel I can recommend ARTI to a friend or relative as a workplace & -0.649 & 0.141 & -4.609 & 0.000 & -1.102 \\
\hline & P07 8: I feel that I have confidence with my boss to talk about different issues & -0.065 & 0.142 & -0.456 & 1.000 & -0.523 \\
\hline & P07 9 : I feel that the founder is close to me and the needs of the company & 0.000 & 0.140 & 0.000 & 1.000 & -0.448 \\
\hline
\end{tabular}




\section{Annex II: T-Test Results (Question 8)}

\begin{tabular}{|c|c|c|c|c|c|c|}
\hline & SATISFACTION & MEDIA & ERROR & T- & PVALE & $\begin{array}{r}\text { CON } \\
\text { INTER }\end{array}$ \\
\hline & & DIFFERENCE & DEVIATION & STATISTIC & & Lower \\
\hline & P08 2: With the rules and regulations & 0.065 & 0.123 & 0.528 & 1.000 & -0.331 \\
\hline & P08_ 3 : With my benefits as an employee & -0.351 & 0.143 & -2.459 & 0.301 & -0.809 \\
\hline & P08_ 4 : With the benefits for my family & -0.494 & 0.152 & -3.240 & 0.047 & -0.984 \\
\hline & P08_5: With the uniform that I use daily & -0.610 & 0.163 & -3.731 & 0.010 & -1.136 \\
\hline P08_1: With work & P08_6: With the facilities and offices & -0.247 & 0.146 & -1.693 & 0.799 & -0.715 \\
\hline & P08_ 7 : With the salary & -0.818 & 0.142 & -5.753 & 0.000 & -1.275 \\
\hline & P08 8: With the amount of work that I perform & -0.299 & 0.140 & -2.141 & 0.503 & -0.747 \\
\hline & P08 9 : With the treatment received from my bosses & 0.000 & 0.120 & 0.000 & 1.000 & -0.385 \\
\hline & P08 10 : With the treatment of my co-workers & 0.130 & 0.128 & 1.019 & 0.991 & -0.280 \\
\hline & P08_1: With work schedules & -0.065 & 0.123 & -0.528 & 1.000 & -0.461 \\
\hline & P08_ 3 : With my benefits as an employee & -0.416 & 0.132 & -3.147 & 0.061 & -0.841 \\
\hline & P08 4 : With the benefits for my family & -0.558 & 0.143 & -3.911 & 0.005 & -1.018 \\
\hline & P08_ 5 : With the uniform that I use daily & -0.675 & 0.154 & -4.372 & 0.001 & -1.173 \\
\hline P08_2: With the rules & P08 6 : With the facilities and offices & -0.312 & 0.136 & -2.300 & 0.397 & -0.748 \\
\hline & P08_ 7 : With the salary & -0.883 & 0.132 & -6.709 & 0.000 & -1.306 \\
\hline & P08_8: With the amount of work that I perform & -0.364 & 0.129 & -2.825 & 0.139 & -0.778 \\
\hline & P08 9 : With the treatment received from my bosses & -0.065 & 0.107 & -0.608 & 1.000 & -0.408 \\
\hline & P08 10 : With the treatment of my co-workers & 0.065 & 0.116 & 0.562 & 1.000 & -0.307 \\
\hline & P08_1: With work schedules & 0.351 & 0.143 & 2.459 & 0.301 & -0.108 \\
\hline & P08 2 : With the rules and regulations & 0.416 & 0.132 & 3.147 & 0.061 & -0.009 \\
\hline & P08_4: With the benefits for my family & -0.143 & 0.160 & -0.895 & 0.996 & -0.656 \\
\hline & P08_5: With the uniform that I use daily & -0.260 & 0.170 & -1.526 & 0.880 & -0.807 \\
\hline P08_3: With my benefits & P08 6: With the facilities and offices & 0.104 & 0.154 & 0.677 & 1.000 & -0.389 \\
\hline & P08 7 : With the salary & -0.468 & 0.150 & -3.119 & 0.065 & -0.949 \\
\hline & P08_8: With the amount of work that I perform & 0.052 & 0.148 & 0.352 & 1.000 & -0.422 \\
\hline & P08_9: With the treatment received from my bosses & 0.351 & 0.129 & 2.724 & 0.176 & -0.064 \\
\hline & PO8_10: With the treatrment of my co-workers & 0.481 & 0.136 & 3.530 & 0.019 & 0.043 \\
\hline & P08__: With work schedules & 0.494 & 0.152 & 3.240 & 0.047 & 0.004 \\
\hline & P08_2: With the rules and regulations & 0.558 & 0.143 & 3.911 & 0.005 & 0.099 \\
\hline & P08_ 3 : With my benefits as an employee & 0.143 & 0.160 & 0.895 & 0.996 & -0.370 \\
\hline & P08_5: With the uniform that I use daily & -0.117 & 0.179 & -0.655 & 1.000 & -0.691 \\
\hline P08_4: With the benefits & P08 6: With the facilities and offices & 0.247 & 0.163 & 1.518 & 0.884 & -0.276 \\
\hline & P08 7 : With the salary & -0.325 & 0.159 & -2.040 & 0.574 & -0.837 \\
\hline & P08_ 8 : With the amount of work that I perform & 0.195 & 0.157 & 1.241 & 0.965 & -0.310 \\
\hline & PO8_-9: With the treatment received from my bosses & 0.494 & 0.140 & 3.539 & 0.020 & 0.044 \\
\hline & P08 10 : With the treatment of my co-workers & 0.623 & 0.146 & 4.254 & 0.002 & 0.152 \\
\hline & P08_1: With work schedules & 0.610 & 0.163 & 3.731 & 0.010 & 0.085 \\
\hline & P08_2: With the rules and regulations & 0.675 & 0.154 & 4.372 & 0.001 & 0.178 \\
\hline & P08_3: With my benefits as an employee & 0.260 & 0.170 & 1.526 & 0.880 & -0.288 \\
\hline & P08_4: With the benefits for my family & 0.117 & 0.179 & 0.655 & 1.000 & -0.457 \\
\hline P08_5: With the uniform & In P08_6: With the facilities and offices & 0.364 & 0.173 & 2.103 & 0.530 & -0.192 \\
\hline & P08_-7: With the salary & -0.208 & 0.170 & -1.224 & 0.968 & -0.754 \\
\hline & P08_8: With the amount of work that I perform & 0.312 & 0.168 & 1.859 & 0.697 & -0.228 \\
\hline & P08_9: With the treatment received from my bosses & 0.610 & 0.152 & 4.025 & 0.004 & 0.122 \\
\hline & P08_ 10 : With the treatment of my co-workers & 0.740 & 0.158 & 4.687 & 0.000 & 0.232 \\
\hline & P08_1:With work schedules & 0.247 & 0.146 & 1.693 & 0.799 & -0.222 \\
\hline & P08_2: With the rules and regulations & 0.312 & 0.136 & 2.300 & 0.397 & -0.125 \\
\hline & P08_3: With my benefits as an employee & -0.104 & 0.154 & -0.677 & 1.000 & -0.597 \\
\hline & P08_4: With the benefits for my family & -0.247 & 0.163 & -1.518 & 0.884 & -0.769 \\
\hline P08_6: With the facilities & P08 5 : With the uniform that I use daily & -0.364 & 0.173 & -2.103 & 0.530 & -0.920 \\
\hline & P08 7 : With the salary & -0.571 & 0.153 & -3.730 & 0.010 & -1.063 \\
\hline & POB_8: With the anount of work that I perform & -0.052 & 0.151 & -0.345 & 1.000 & -0.536 \\
\hline & P08_9: With the treatment received from my bosses & 0.247 & 0.132 & 1.865 & 0.693 & -0.179 \\
\hline & P08_ 10 : With the treatment of my co-workers & 0.377 & 0.140 & 2.700 & 0.185 & -0.072 \\
\hline & P08_1: With work schedules & 0.818 & 0.142 & 5.753 & 0.000 & 0.362 \\
\hline & P08_2: With the rules and regulations & 0.883 & 0.132 & 6.709 & 0.000 & 0.460 \\
\hline & P08_3: With my benefits as an employee & 0.468 & 0.150 & 3.119 & 0.065 & -0.014 \\
\hline & P08_4: With the benefits for my family & 0.325 & 0.159 & 2.040 & 0.574 & -0.187 \\
\hline P08 7 : With the salary & P08_5: With the uniform that I use daily & 0.208 & 0.170 & 1.224 & 0.968 & -0.338 \\
\hline & P08_6: With the facilities and offices & 0.571 & 0.153 & 3.730 & 0.010 & 0.080 \\
\hline & PO8_8: With the amount of work that I perform & 0.519 & 0.147 & 3.528 & 0.019 & 0.047 \\
\hline & PO8_-9: With the treatment received from my bosses & 0.818 & 0.128 & 6.376 & 0.000 & 0.405 \\
\hline & P08_ 10 : With the treatment of my co-workers & 0.948 & 0.136 & 6.985 & 0.000 & 0.512 \\
\hline & P08_1: With work schedules & 0.299 & 0.140 & 2.141 & 0.503 & -0.150 \\
\hline & P08_2: With the rules and regulations & 0.364 & 0.129 & 2.825 & 0.139 & -0.051 \\
\hline & P08_- 3 : With my benefits as an employee & -0.052 & 0.148 & -0.352 & 1.000 & -0.526 \\
\hline & P08_4: With the benefits for my family & -0.195 & 0.157 & -1.241 & 0.965 & -0.699 \\
\hline he amount & P08 5 : With the uniform that I use daily & -0.312 & 0.168 & -1.859 & 0.697 & -0.851 \\
\hline & P08_6: With the facilities and offices & 0.052 & 0.151 & 0.345 & 1.000 & -0.432 \\
\hline & P08_7: With the salary & -0.519 & 0.147 & -3.528 & 0.019 & -0.992 \\
\hline & P08_9: With the treatment received from my bosses & 0.299 & 0.125 & 2.383 & 0.345 & -0.105 \\
\hline & P08_ 10 : With the treatnent of my co-workers & 0.429 & 0.133 & 3.224 & 0.049 & 0.001 \\
\hline & P08_1: With work schedules & 0.000 & 0.120 & 0.000 & 1.000 & -0.385 \\
\hline & P08_2: With the rules and regulations & 0.065 & 0.107 & 0.608 & 1.000 & -0.278 \\
\hline & P08_3: With my benefits as an employee & -0.351 & 0.129 & -2.724 & 0.176 & -0.765 \\
\hline & PO8_ 4 : With the benefits for my family & -0.494 & 0.140 & -3.539 & 0.020 & -0.943 \\
\hline treatment received from & P08_5: With the uniform that I use daily & -0.610 & 0.152 & -4.025 & 0.004 & -1.099 \\
\hline & P08_6: With the facilities and offices & -0.247 & 0.132 & -1.865 & 0.693 & -0.673 \\
\hline & P08_7: With the salary & -0.818 & 0.128 & -6.376 & 0.000 & -1.231 \\
\hline & P08 \& 8 : With the amount of work that I perform & -0.299 & 0.125 & -2.383 & 0.345 & -0.702 \\
\hline & P08_10: With the treatment of my co-workers & 0.130 & 0.112 & 1.162 & 0.977 & -0.230 \\
\hline & P08_1: With work schedules & -0.130 & 0.128 & -1.019 & 0.991 & -0.540 \\
\hline & P08_2: With the rules and regulations & -0.065 & 0.116 & -0.562 & 1.000 & -0.436 \\
\hline & P08_3: With my benefits as an employee & -0.481 & 0.136 & -3.530 & 0.019 & -0.918 \\
\hline & P08_4: With the benefits for my family & -0.623 & 0.146 & -4.254 & 0.002 & -1.094 \\
\hline & P08_5: With the uniform that I use daily & -0.740 & 0.158 & -4.687 & 0.000 & -1.249 \\
\hline & P08_6: With the facilities and offices & -0.377 & 0.140 & -2.700 & 0.185 & -0.825 \\
\hline & P08 7 : With the salary & -0.948 & 0.136 & -6.985 & 0.000 & -1.384 \\
\hline & P08 8 : With the amount of work that I perform & -0.429 & 0.133 & -3.224 & 0.049 & -0.856 \\
\hline & P08_9: With the treatment received from my bosses & -0.130 & 0.112 & -1.162 & 0.977 & -0.489 \\
\hline
\end{tabular}




\section{Annex III: T-Test Results (Strategic elements; Question 9)}

T-TEST RESULTS (STRATEGIC ELEMENTS)

\begin{tabular}{|c|c|c|c|c|c|c|c|}
\hline \multirow{2}{*}{\multicolumn{2}{|c|}{ Strategic Elements }} & \multirow{2}{*}{$\begin{array}{c}\text { MEDIA } \\
\text { DIFFERENCE }\end{array}$} & \multirow{2}{*}{$\begin{array}{c}\text { ERROR } \\
\text { DEVIATION }\end{array}$} & \multirow{2}{*}{$\begin{array}{c}\text { T- } \\
\text { STATISTIC }\end{array}$} & \multirow[t]{2}{*}{ PVALUE } & \multicolumn{2}{|c|}{$\begin{array}{c}\text { CONFIDENCE INTERVAL } \\
\text { AT 95\% } \\
\end{array}$} \\
\hline & & & & & & Lower Limit & Upper Limit \\
\hline \multirow{6}{*}{$\begin{array}{l}\text { P09_1 : It has good } \\
\text { products quality and price }\end{array}$} & P09 2: The bosses care about their workers & -0.364 & 0.109 & -3.337 & 0.018 & -0.69 & -0.04 \\
\hline & P09_3: For the good administrative and management processes & -0.481 & 0.109 & -4.400 & 0.000 & -0.81 & -0.15 \\
\hline & P09 4: For the care and concern for the financial statements & -0.169 & 0.103 & -1.636 & 0.660 & -0.48 & 0.14 \\
\hline & P09_5: Good customer service & -0.156 & 0.099 & -1.578 & 0.698 & -0.45 & 0.14 \\
\hline & P09_6: For ensuring a good culture in the company & -0.195 & 0.089 & -2.180 & 0.314 & -0.46 & 0.07 \\
\hline & P09 7: For the leadership of the founder & 0.260 & 0.093 & 2.800 & 0.083 & -0.02 & 0.54 \\
\hline \multirow{6}{*}{$\begin{array}{c}\text { P09_2: The bosses care } \\
\text { about their workers }\end{array}$} & P09_1 : It has good products quality and price & 0.364 & 0.109 & 3.337 & 0.018 & 0.04 & 0.69 \\
\hline & P09 3: For the good administrative and management processes & -0.117 & 0.121 & -0.971 & 0.960 & -0.48 & 0.24 \\
\hline & P09_4: For the care and concern for the financial statements & 0.195 & 0.115 & 1.694 & 0.622 & -0.15 & 0.54 \\
\hline & P09_5: Good customer service & 0.208 & 0.111 & 1.871 & 0.504 & -0.12 & 0.54 \\
\hline & P09_6: For ensuring a good culture in the company & 0.169 & 0.103 & 1.643 & 0.656 & -0.14 & 0.48 \\
\hline & P09 7: For the leadership of the founder & 0.623 & 0.106 & 5.887 & 0.000 & 0.31 & 0.94 \\
\hline \multirow{6}{*}{$\begin{array}{l}\text { P09_3: For the good } \\
\text { administrative and } \\
\text { management processes }\end{array}$} & P09_1: It has good products quality and price & 0.481 & 0.109 & 4.400 & 0.000 & 0.15 & 0.81 \\
\hline & P09_2: The bosses care about their workers & 0.117 & 0.121 & 0.971 & 0.960 & -0.24 & 0.48 \\
\hline & P09_4: For the care and concern for the financial statements & 0.312 & 0.115 & 2.705 & 0.105 & -0.03 & 0.66 \\
\hline & P09-5: Good customer service & 0.325 & 0.111 & 2.917 & 0.061 & -0.01 & 0.66 \\
\hline & P09_6 : For ensuring a good culture in the company & 0.286 & 0.103 & 2.774 & 0.089 & -0.02 & 0.59 \\
\hline & P09 7: For the leadership of the founder & 0.740 & 0.106 & 6.976 & 0.000 & 0.42 & 1.06 \\
\hline \multirow{6}{*}{$\begin{array}{l}\text { P09_4: For the care and } \\
\text { concern for the financial } \\
\text { statements }\end{array}$} & P09_1 : It has good products quality and price & 0.169 & 0.103 & 1.636 & 0.660 & -0.14 & 0.48 \\
\hline & P09 2: The bosses care about their workers & -0.195 & 0.115 & -1.694 & 0.622 & -0.54 & 0.15 \\
\hline & P09_3: For the good administrative and management processes & -0.312 & 0.115 & -2.705 & 0.105 & -0.66 & 0.03 \\
\hline & P09_5: Good customer service & 0.013 & 0.105 & 0.123 & 1.000 & -0.30 & 0.33 \\
\hline & P09_6: For ensuring a good culture in the company & -0.026 & 0.097 & -0.269 & 1.000 & -0.32 & 0.26 \\
\hline & P09 7: For the leadership of the founder & 0.429 & 0.100 & 4.297 & 0.001 & 0.13 & 0.73 \\
\hline \multirow{6}{*}{$\begin{array}{c}\text { P09_5 : Good customer } \\
\text { service }\end{array}$} & P09_1 : It has good products quality and price & 0.156 & 0.099 & 1.578 & 0.698 & -0.14 & 0.45 \\
\hline & P09_2: The bosses care about their workers & -0.208 & 0.111 & -1.871 & 0.504 & -0.54 & 0.12 \\
\hline & P09_3: For the good administrative and management processes & -0.325 & 0.111 & -2.917 & 0.061 & -0.66 & 0.01 \\
\hline & P09_4: For the care and concern for the financial statements & -0.013 & 0.105 & -0.123 & 1.000 & -0.33 & 0.30 \\
\hline & P09_6: For ensuring a good culture in the company & -0.039 & 0.092 & -0.424 & 1.000 & -0.31 & 0.24 \\
\hline & P09 7: For the leadership of the founder & 0.416 & 0.095 & 4.366 & 0.000 & 0.13 & 0.70 \\
\hline \multirow{6}{*}{$\begin{array}{l}\text { P09_6 : For ensuring a } \\
\text { good culture in the } \\
\text { company }\end{array}$} & P09_1: It has good products quality and price & 0.195 & 0.089 & 2.180 & 0.314 & -0.07 & 0.46 \\
\hline & P09_2: The bosses care about their workers & -0.169 & 0.103 & -1.643 & 0.656 & -0.48 & 0.14 \\
\hline & P09_3: For the good administrative and management processes & -0.286 & 0.103 & -2.774 & 0.089 & -0.59 & 0.02 \\
\hline & P09_4: For the care and concern for the financial statements & 0.026 & 0.097 & 0.269 & 1.000 & -0.26 & 0.32 \\
\hline & P09_5: Good customer service & 0.039 & 0.092 & 0.424 & 1.000 & -0.24 & 0.31 \\
\hline & P09 7: For the leadership of the founder & 0.455 & 0.085 & 5.327 & 0.000 & 0.20 & 0.71 \\
\hline \multirow{6}{*}{$\begin{array}{l}\text { P09_7: For the } \\
\text { leadership of the founder }\end{array}$} & P09_1: It has good products quality and price & -0.26 & 0.093 & -2.800 & 0.083 & -0.54 & 0.02 \\
\hline & P09_2: The bosses care about their workers & -0.623 & 0.106 & -5.887 & 0.000 & -0.94 & -0.31 \\
\hline & P09_3: For the good administrative and management processes & -0.740 & 0.106 & -6.976 & 0.000 & -1.06 & -0.42 \\
\hline & P09_4: For the care and concern for the financial statements & -0.429 & 0.100 & -4.297 & 0.001 & -0.73 & -0.13 \\
\hline & P09_5 : Good customer service & -0.416 & 0.095 & -4.366 & 0.000 & -0.70 & -0.13 \\
\hline & P09 6: For ensuring a good culture in the company & -0.455 & 0.085 & -5.327 & 0.000 & -0.71 & -0.20 \\
\hline
\end{tabular}


